\title{
Systemic Morphine-Induced Fos Protein in the Rat Striatum and Nucleus Accumbens Is Regulated by $\mu$ Opioid Receptors in the Substantia Nigra and Ventral Tegmental Area
}

\author{
Bruno Bontempi and Frank R. Sharp \\ Department of Neurology (V127), University of California at San Francisco and Department of Veterans Affairs Medical \\ Center, San Francisco, California 94121
}

\begin{abstract}
To characterize how systemic morphine induces Fos protein in dorsomedial striatum and nucleus accumbens (NAc), we examined the role of receptors in striatum, substantia nigra (SN), and ventral tegmental area (VTA). Morphine injected into medial SN or into VTA of awake rats induced Fos in neurons in ipsilateral dorsomedial striatum and NAc. Morphine injected into lateral SN induced Fos in dorsolateral striatum and globus pallidus. The morphine infusions produced contralateral turning that was most prominent after lateral SN injections. Intranigral injections of $\left[\mathrm{D}-\mathrm{Ala}^{2}, \mathrm{~N}\right.$-Me-Phe ${ }^{4}$, Gly-ol $\left.{ }^{5}\right]$-enkephalin (DAMGO), a $\mu$ opioid receptor agonist, and of bicuculline, a $\mathrm{GABA}_{\mathrm{A}}$ receptor antagonist, induced Fos in ipsilateral striatum. Fos induction in dorsomedial striatum produced by systemic administration of morphine was blocked by (1) SN and VTA injections of the $\mu_{1}$ opioid antagonist naloxonazine and (2) striatal injections of either MK 801, an NMDA glutamate receptor antagonist, or $\mathrm{SCH} 23390$, a $\mathrm{D}_{1}$ dopamine receptor antagonist.
\end{abstract}

Fos induction in dorsomedial striatum and NAc after systemic administration of morphine seems to be mediated by dopamine neurons in medial SN and VTA that project to medial striatum and NAc, respectively. Systemic morphine is proposed to act on $\mu$ opioid receptors located on GABAergic interneurons in medial SN and VTA. Inhibition of these GABA interneurons disinhibits medial SN and VTA dopamine neurons, producing dopamine release in medial striatum and NAc. This activates $D_{1}$ dopamine receptors and coupled with the coactivation of NMDA receptors possibly from cortical glutamate input induces Fos in striatal and NAc neurons. The modulation of target gene expression by Fos could influence addictive behavioral responses to opiates.

Key words: morphine; immediate early genes; Fos; drug addiction; rotational behavior; striatum; substantia nigra; ventral tegmental area; nucleus accumbens; Parkinson's disease
The $c$-fos and junB immediate early genes (IEGs) are induced in striatum and nucleus accumbens (NAc) after systemic administration of cocaine and amphetamine (Graybiel et al., 1990; Robertson et al., 1991; Cenci et al., 1992; Hope et al., 1992; Moratalla et al., 1993, 1996; Steiner and Gerfen, 1993, 1995; Johansson et al., 1994). This IEG induction is mediated by dopamine because $\mathrm{D}_{1}$ dopamine receptor antagonists block induction of $c$-fos and junB (Graybiel et al., 1990; Young et al., 1991; Cole et al., 1992).

Dopamine is hypothesized to mediate some of the reward, addictive, motor, and other behavioral properties of drugs of abuse (Akil et al., 1984; Bozarth and Wise, 1984; Di Chiara and Imperato, 1988a; Koob and Bloom, 1988; Wise and Rompre, 1989; Di Chiara and North, 1992; Koob, 1992; Nestler, 1992; Nestler et al., 1993). This hypothesis received further support when systemic morphine was also shown to induce c-fos and junB in the medial striatum and NAc, and this IEG induction was blocked by the systemic administration of the $\mathrm{D}_{1}$ dopamine receptor antagonists SCH 39166 and SCH 23390 (Liu et al., 1994).

Although the IEG induction produced by cocaine and amphet-

Received April 4, 1997; revised Aug. 6, 1997; accepted Aug. 21, 1997.

This work was supported by National Institutes of Health Grant NS28167. B.B. was supported by a postdoctoral fellowship from the FYSSEN Foundation (Paris, France) during the course of this investigation. We thank Dr. J. Liu and E. Lee for technical assistance. We are also grateful to Dr. S. M. Sagar and Dr. M. Sganga for their support and helpful comments on this manuscript.

Correspondence should be addressed to Dr. Frank R. Sharp, Department of Neurology (V127), Veterans Affairs Medical Center, 4150 Clement Street, San Francisco, CA 94121.

Copyright (C) 1997 Society for Neuroscience $\quad 0270-6474 / 97 / 178596-17 \$ 05.00 / 0$ amine might be explained by the effects of these drugs on dopamine release and reuptake (Cooper et al., 1991; Boja et al., 1994; Hoffman, 1994), it is less clear how systemic morphine induces IEGs in limbic striatum and NAc. Morphine increases the firing rates of dopamine neurons in substantia nigra $(\mathrm{SN})$ and ventral tegmental area (VTA) and increases dopamine release in striatum and NAc (Matthews and German, 1984; Di Chiara and Imperato, 1988a; Spangel et al., 1990; Di Chiara and North, 1992). Because morphine binds to inhibitory $\mu$ opioid receptors (Laugwitz et al., 1992), it has been proposed that morphine acts on $\mu$ receptors located on GABA interneurons in substantia nigra pars reticulata (SNr) and VTA (Di Chiara and North, 1992; Johnson and North, 1992). This would disinhibit SN pars compacta (SNc) and VTA dopamine neurons, increase dopamine neuronal firing, and induce dopamine release in striatum and NAc.

On the basis of this hypothesis, the present study first determined whether morphine and $\mu$ opioid receptor agonist infusions into $\mathrm{SNr}$ /VTA of awake rats induced Fos protein in striatum/ NAc, and whether infusion of a $\mu_{1}$ opioid receptor antagonist into SNr/VTA blocked Fos induction in striatum after systemic morphine administration. Because glutamate receptors regulate mesolimbic and nigrostriatal dopaminergic neurons (S. W. Johnson et al., 1992; Fitzgerald et al., 1996), we postulated that Fos induction in striatum was mediated by NMDA glutamate and $D_{1}$ dopamine receptors located in striatum. Therefore, NMDA and $\mathrm{D}_{1}$ receptor antagonists were inf used into striatum to determine whether they would block Fos induction produced by systemic 
morphine. Finally, because SN and VTA morphine injections produce increased dopamine release and contralateral turning behavior (Iwamoto and Way, 1977; Devine and Wise, 1994), we postulated that the pattern of Fos expression in striatum would correlate with the rotational behavior.

Preliminary results of this study have been published previously in abstract form (Bontempi et al., 1995).

\section{MATERIALS AND METHODS}

Animals and surgery. One hundred and twelve female albino Sprague Dawley rats (Simonsen, Gilroy, CA), weighing between 260 and $300 \mathrm{gm}$, were maintained on a $12 \mathrm{hr}$ light/dark cycle (lights on at 7 A.M.) in a temperature-controlled facility $\left(22 \pm 1^{\circ} \mathrm{C}\right)$. Animals were housed individually in plastic cages with free access to food and water. All procedures were conducted at the same time every day. Under deep ketamine and xylazine anesthesia ( 80 and $12 \mathrm{mg} / \mathrm{kg}$, i.p., respectively), rats were placed in a stereotaxic frame (Kopf Instruments, Tujunga, CA) with the incisor bar set $3.3 \mathrm{~mm}$ below the interaural line. They were implanted bilaterally with 26 gauge stainless steel guide cannulas (Plastics One, Roanoke, VA) in the SNr, the VTA, or the striatum using the following coordinates (Paxinos and Watson, 1986): (1) SNr: anteroposterior (AP) relative to bregma, $-5.6 \mathrm{~mm}$; lateral $(\mathrm{L})$ to the midsagittal suture, \pm 2.0 $\mathrm{mm}$; ventral (V) from the surface of the skull, $-7.0 \mathrm{~mm}$; (2) VTA: AP, $-5.3 \mathrm{~mm}$; L, $\pm 0.6 \mathrm{~mm}$; V, $-7.4 \mathrm{~mm}$; (3) striatum: AP, $+0.5 \mathrm{~mm}$;, \pm 3.0 $\mathrm{mm} ; \mathrm{V},-4.4 \mathrm{~mm}$. To minimize tissue damage, each guide was positioned $1 \mathrm{~mm}$ above the target injection site and anchored to the skull with two stainless steel screws and rapid-setting acrylic dental cement. Patency was maintained by inserting a stylet that projected $1 \mathrm{~mm}$ beyond the tip of each guide cannula. Rats were allowed 1 week to recover from these operations.

Injection procedure. Local injections of the different drugs were made by inserting a 33 gauge injection cannula through the guide cannula in awake, freely moving animals. The injection cannula projected $1 \mathrm{~mm}$ beyond the tip of the guide and was anchored to the guide by means of a plastic connector that was screwed onto the guide. Polyethylene tubing connected the injection cannula to a $5 \mu$ l Hamilton syringe mounted on a Harvard injection pump. Drugs were injected at a rate of $0.4 \mu \mathrm{l} / \mathrm{min}$, with volumes of $0.5,0.3$, and $2 \mu \mathrm{l}$ inf used into the SNr, the VTA, and the striatum, respectively. The injection cannula was left in place for 2 min after the infusion. After removal of the cannula, animals were left in their cage, and their behavior was recorded. The bilateral drug/vehicle injections (left/right) were counterbalanced for each brain site tested. For experiments requiring intraperitoneal injections, a catheter (SILASTIC, outer diameter, 0.037 inches, inner diameter, 0.020 inches; Dow Corning, Midland, MI) was inserted intraperitoneally, tunneled under the skin, exited between the shoulders, and sutured into place the day before intracranial injections.

Drug treatments. Morphine sulfate (Elkins-Sinn, Cherry Hill, NJ) was dissolved in sterile saline and administered intracerebrally into the $\mathrm{SNr}$ $(1,5,7.5$, and $10 \mu \mathrm{g})$ or intraperitoneally via intraperitoneal catheters $(10$ $\mathrm{mg} / \mathrm{kg}$ in a volume of $1 \mathrm{ml} / \mathrm{kg}$, every $30 \mathrm{~min}$ for $2 \mathrm{hr}$ ). All other drugs were purchased from Research Biochemicals International (Natick, MA) and injected intracerebrally. The $\mu$ opioid receptor agonist [D-Ala ${ }^{2}$, $N$-Me-Phe ${ }^{4}, \mathrm{Gly}_{\mathrm{ol}}{ }^{5}$-enkephalin (DAMGO) $(0.1-5.0 \mu \mathrm{g})$, the $\mathrm{GABA}_{\mathrm{A}}$ receptor antagonist bicuculline $(0.05-1.0 \mu \mathrm{g})$, the selective noncompetitive NMDA glutamate receptor antagonist MK $801(0.1-2 \mu \mathrm{g})$, and the selective $\mathrm{D}_{1}$ dopamine receptor antagonist SCH $23390(0.1-2 \mu \mathrm{g})$ were prepared in sterile distilled water. The $\mu_{1}$ opioid receptor antagonist naloxonazine was initially dissolved in distilled water containing $0.1 \mathrm{~N}$ $\mathrm{HCl}$ and then diluted with the appropriate volume of water to reach the final concentration $(0.5-2 \mu \mathrm{g}$; $\mathrm{pH}$ of final solution adjusted to 7.0 by the addition of $10 \mathrm{~N} \mathrm{NaOH}$ ). Although this compound is selective for the $\mu_{1}$ receptor subclass, it also has a high affinity for both of the traditional $\mu$ and $\delta$ receptors (Cruciani et al., 1987; Nock et al., 1993). A significant action on $\delta$ receptors is unlikely because of their low density in $\mathrm{SNr}$ and their absence in VTA (Mansour et al., 1987). We cannot exclude, however, an action of naloxonazine, even at the lowest doses, on traditional $\mu$ receptors (Fowler and Fraser, 1994). This compound was therefore considered a general $\mu$ opioid receptor antagonist in the present study. All antagonists were injected intracerebrally $30 \mathrm{~min}$ before the systemic morphine injections. Animal behavior was recorded and the number of rotations $\left(360^{\circ}\right.$ contraversive turns) made in consecutive 10 min periods was counted from the time immediately after each intracerebral injection until the animal was anesthetized.
Immunocytochemistry. Animals were deeply anesthetized $2 \mathrm{hr}$ after the last drug injection and perfused transcardially with $400 \mathrm{ml}$ of saline followed by $350 \mathrm{ml}$ of cold $4 \%$ paraformaldehyde in $0.1 \mathrm{M}$ phosphate buffer, $\mathrm{pH}$ 7.4. Brains were dissected and post-fixed overnight, and $100-\mu \mathrm{m}$-thick coronal sections were cut on a vibratome. Selected sections were stained using cresyl violet to identify guide tracks and injection sites. Only the animals with a cannula tip located within the targeted structure were included in the data analysis. Immunocytochemistry was performed on free-floating sections as described previously (Sharp et al., 1991; Sharp and Sagar, 1995) using a standard avidin-biotin (ABC) peroxidase method (Elite Vectastain Kit, Vector Laboratories, Burlingame, CA). The peroxidase was detected with diaminobenzidine (DAB; Sigma, St. Louis, MO). The primary antibody was a mouse monoclonal antibody (LA041, 1:35000) raised to a synthetic peptide derived from amino acid sequences $4-17$ of the Fos protein. The antibody produces one band on Western blots (De Togni et al., 1988) and produces patterns of Fos immunostaining that are identical to $c$-fos mRNA induction using in situ hybridization (Sharp et al., 1991). Control sections displayed no staining when incubated without primary antibody.

Cell counting and image analysis. Quantitative analysis of Fos-positive nuclei was performed using an MCID computerized image processing system interfaced to a Nikon HFX-II microscope. The striatum, globus pallidus (GP), and NAc were anatomically defined according to the Paxinos and Watson atlas (1986). The number of Fos-immunoreactive neurons in these regions was counted bilaterally using a minimum of four consecutive sections for each animal. Counts in striatum were obtained from either an entire cross section or from certain dorsomedial or dorsolateral portions of striatum (see Fig. $1 B$ ). Counts in NAc included all cells in both the core and shell regions performed at roughly $+0.7 \mathrm{~mm}$ anterior to bregma in the region shown by the dotted lines in Figure $1 B$. A constant density threshold operation and target acceptance criterion were used to record the number of Fos-positive nuclei for each of the sections. These numbers were then averaged for each animal in each group to give the final means and statistics.

Statistics. All Fos cell counts were expressed as mean \pm SEM. Differences between groups were assessed using an ANOVA followed by post hoc paired comparisons using the Scheffe F-test. Similar statistics were performed on mean rotation rates calculated over 30 min periods after the drug injection. Correlation between numbers of Fos-stained neurons and rotational behavior was obtained by linear regression analysis and determination of the Pearson product-moment correlation coefficient. For all comparisons, values of $p<0.05$ were considered as statistically significant.

\section{RESULTS \\ Cannula placements}

Injection sites in the midbrain and striatum were identified on cresyl violet-stained sections by using the track of the guide and the injection cannula. The stained sections were imaged with the MCID computer-based system, and regions of decreased staining were used to define injection sites. The optical density within injection tracks was generally $30 \%$ less than the density of cells in surrounding brain areas. The deepest point in each structure showing decreased staining on three to four adjacent sections through the area of the injection was defined as the injection site. Composites of enlarged brain regions containing the injection sites were traced from the MCID digitized image and compared with coronal sections depicted in the Paxinos and Watson (1986) atlas (Fig. $1 A, B$ ). The injection site was determined in every animal. There did not appear to be extensive damage to brain tissue around the injection cannula track (Fig. 2).

Figures $1 A$ and 2 show the $\mathrm{SNr}$ injection sites. Only the animals with injections located between 5.2 and $6.0 \mathrm{~mm}$ posterior to bregma were included in the study. Figure $1 B$ indicates the striatal injection sites. The VTA naloxonazine and morphine injection sites are shown in Figures $1 A$ and $7 B$, respectively. 
A
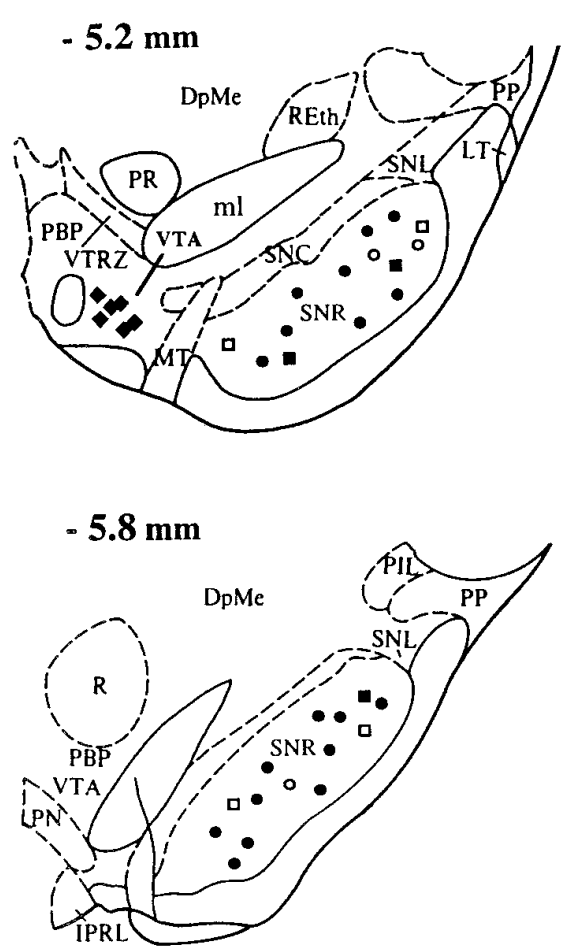

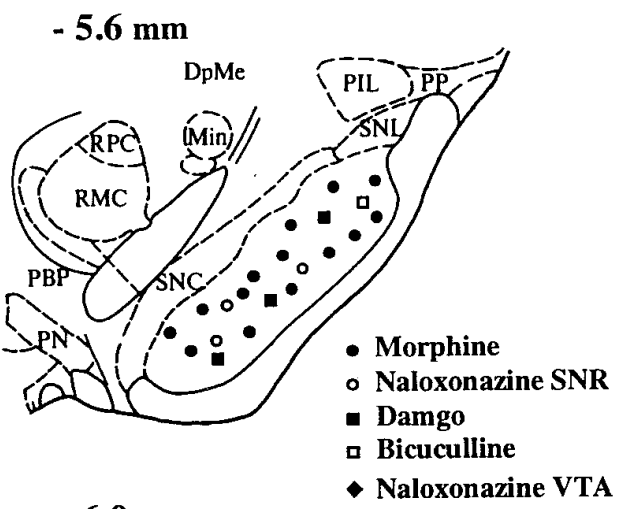

$-6.0 \mathrm{~mm}$

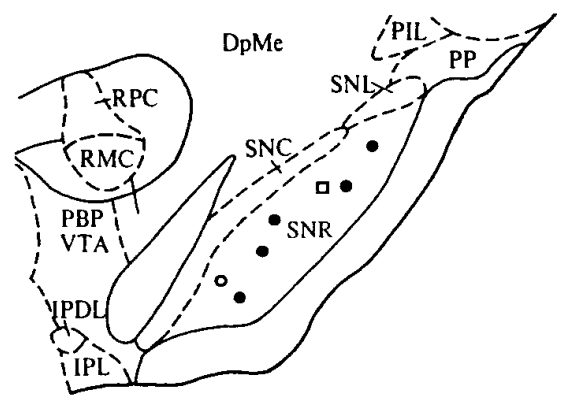

Figure 1. A, Injection sites are plotted on coronal brain sections for the rats that received $0.5 \mu \mathrm{l}$ injections into the substantia nigra pars reticulata $(S N R)$ of morphine $(1,5,7.5$, and $10 \mu \mathrm{g} ; n=$ 37; filled circles $)$, DAMGO (1 $\mu \mathrm{g} ; n=$ 6 ; filled squares), naloxonazine $(0.5 \mu \mathrm{g}$; $n=7$; open circles), or bicuculline (0.5 $\mu \mathrm{g} ; n=6$; open squares). Each symbol corresponds to the deepest penetration of the cannula track. The distance from bregma for each section is given in millimeters. The placements of the injection sites in the ventral tegmental area $(V T A)$ for the animals that received $0.3 \mu \mathrm{l}$ injections of naloxonazine $(0.5 \mu \mathrm{g} ; n=6$; filled diamonds $)$ are plotted on a single plane $(-5.2 \mathrm{~mm})$ (adapted from Paxinos and Watson, 1986). $B$, Injection sites are plotted on coronal brain sections for the animals that received $2 \mu \mathrm{l}$ injections into the striatum of either the $\mathrm{D}_{1}$ dopamine receptor antagonist SCH $23390(0.1 \mu \mathrm{g}$; $n=7$; open circles) or the NMDA glutamate receptor antagonist MK 801 $(0.1 \mu \mathrm{g} ; n=7 ;$ filled circles $)$. Although injection sites were made between 0.2 and $0.8 \mathrm{~mm}$ anterior to bregma, they are represented on a single plane $(+0.7$ $\mathrm{mm}$ ) (redrawn from Paxinos and Watson, 1986). The dotted lines indicate how the striatum was arbitrarily divided into four areas within which quantitative analyses of Fos-positive neurons were performed. $S T$, Striatum; $A c b S h$, nucleus accumbens shell; $A c b C$ nucleus accumbens core (for complete listing of all abbreviations, see Paxinos and Watson, 1986).

\section{B}

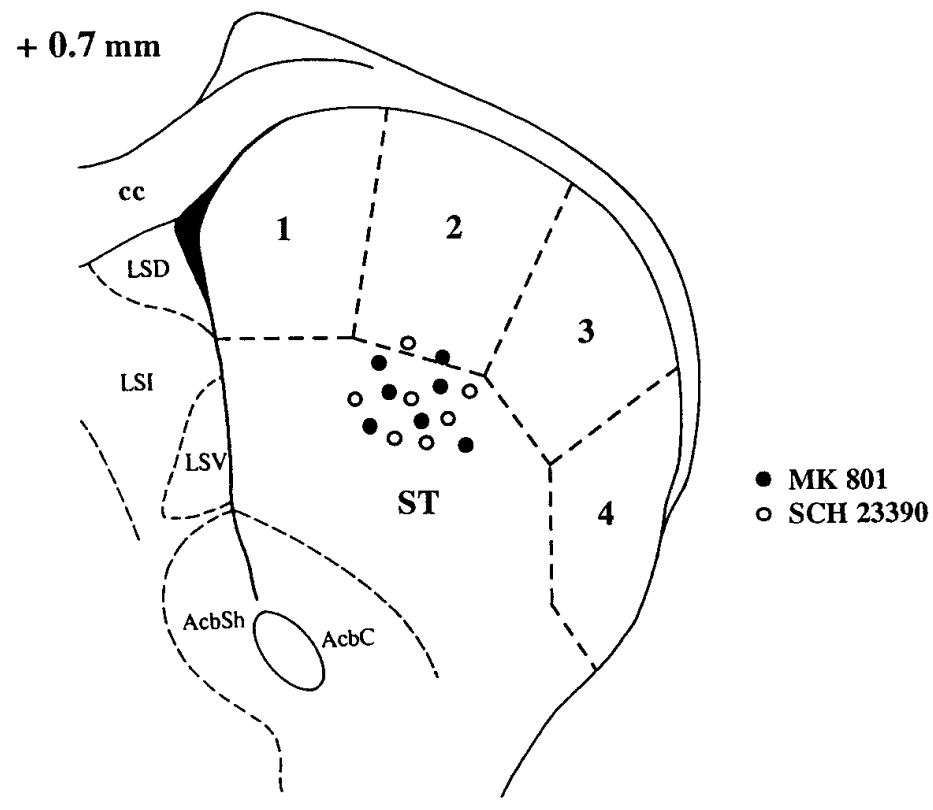

\section{Effects of intranigral injections of morphine on Fos immunoreactivity in striatum and rotational behavior}

Morphine injections $(1,5,7.5$, and $10 \mu \mathrm{g})$ into the $\mathrm{SNr}$ produced a dose-dependent increase $\left(F_{(4,69)}=127.15 ; p<0.001\right)$ in the number of Fos-immunoreactive neurons in the ipsilateral striatum (Fig. 3A). The greatest induction of Fos in striatum occurred after injections of $10 \mu \mathrm{g}$ of morphine into $\mathrm{SNr}(p<0.001)$ (Fig. $3 A, B$, right panel) compared with very few cells in the opposite striatum after saline injections into the opposite $\mathrm{SNr}$ (Fig. 3A,B, left panel).

Morphine injections caused a dose-dependent increase $\left(F_{(4,40)}\right.$ $=12.36 ; p<0.001$ ) in rotational behavior (Fig. 3A). Animals rotated away from the injection site in $\mathrm{SNr}$ (contraversive turning) and showed a tight "nose-to-tail" posture with the highest doses $(7.5$ and $10 \mu \mathrm{g})$ of morphine. Linear regression analysis (Fig. 4) revealed that the total number of Fos-positive nuclei in 

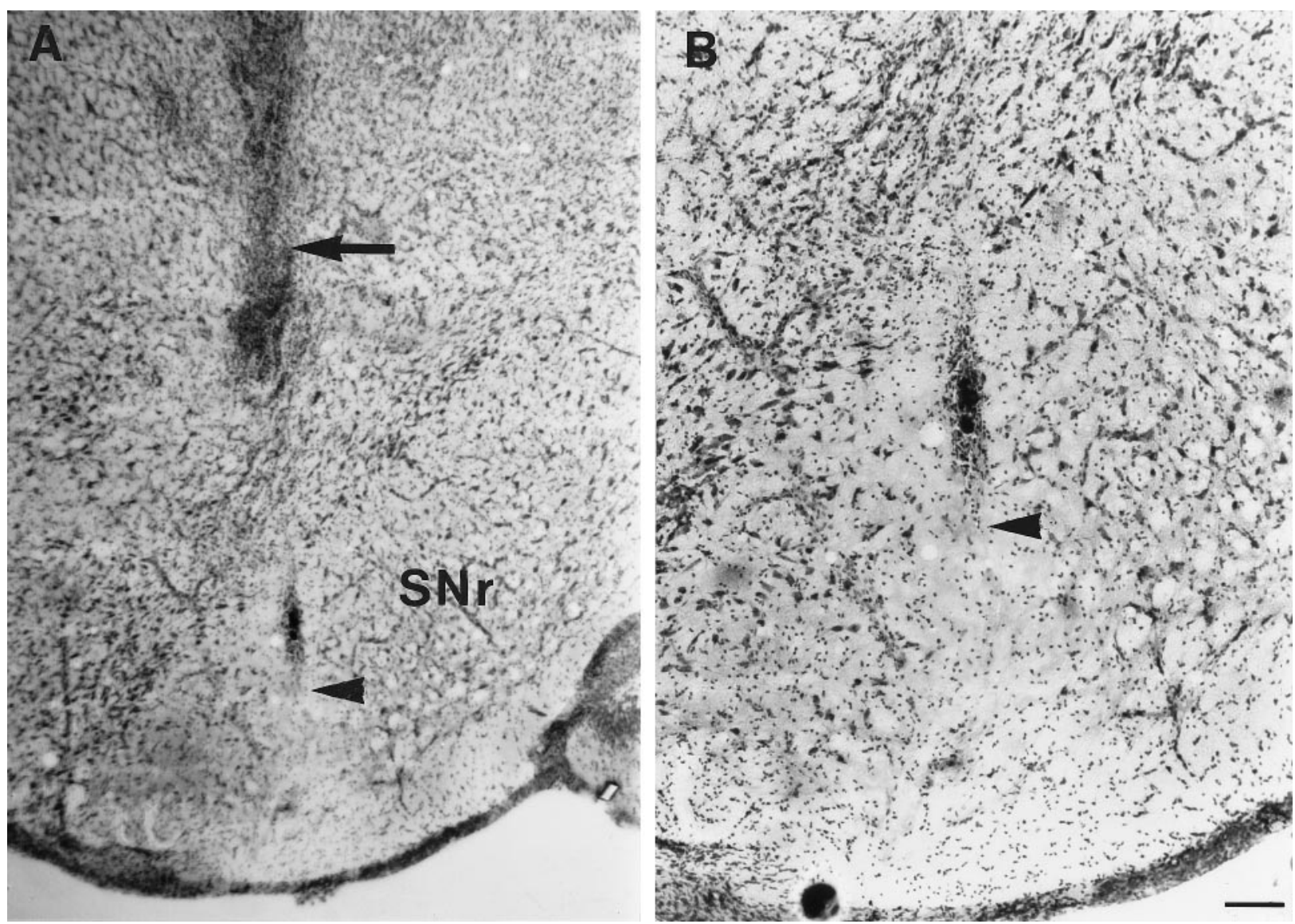

Figure 2. A, Photomicrograph of a cresyl violet-stained section showing the locations of the guide cannula track (arrow) and the tip of the internal cannula (arrowhead) after injection of morphine into medial substantia nigra pars reticulata $(S N r)$. $B$, Higher power view of $A$ showing the injection site. Scale bar (shown in $B$ ): $A, 100 \mu \mathrm{m} ; B, 50 \mu \mathrm{m}$.

the striatum after ipsilateral morphine injections into $\mathrm{SNr}$ (all doses combined) was significantly and positively correlated with the number of rotations $\left(r=+0.73 ; F_{(1,35)}=39.55 ; p<0.001\right)$. The greater the number of rotations that occurred in a $30 \mathrm{~min}$ period, the higher the total number of Fos-stained neurons in striatum. All morphine-injected animals turned for at least $30 \mathrm{~min}$ after the injections (Fig. $3 A$ ). However, a time-dependent effect of morphine on the rotational behavior was also observed. The duration of turning over a $2 \mathrm{hr}$ period was found to be dependent on the initial amount of morphine injected: the longest duration of turning ( $2 \mathrm{hr}$ ) was observed in animals infused with $10 \mu \mathrm{g}$ of morphine, and the shortest duration of turning (30 min) was observed in animals inf used with $1 \mu \mathrm{g}$ of morphine into $\mathrm{SNr}(p<$ 0.01; data not shown). This may be related to the short half-life of morphine (30-40 min) in the brain (Bhargava et al., 1992).

Three different patterns of Fos expression were observed in the striatum after morphine injections into SNr. Figure 5 demonstrates these patterns in the subjects injected with $10 \mu \mathrm{g}$ of morphine. Some of these animals exhibited Fos immunostaining localized mostly to the dorsomedial striatum (Fig. 5A2; "medial pattern" group), with little staining in lateral striatum (Fig. 5A1). Some of the subjects had Fos-stained cells localized mostly to dorsolateral and far lateral striatum (Fig. 5C5; "lateral pattern" group), with fewer stained cells in dorsomedial striatum (Fig. 5C6). The remaining subjects had Fos-immunostained nuclei throughout striatum, in both medial (Fig. 5B4) and lateral (Fig. $5 B 3$ ) portions of the striatum ("mediolateral pattern" group).
To quantify this distribution and to determine whether the patterns of striatal staining were related to the morphine injection sites in $\mathrm{SNr}$, the striatum was arbitrarily divided into four areas as shown in Figure $1 B$, area 1 being the most dorsomedial and area 4 being the most dorsolateral. Counts of Fos-positive neurons were performed for each area in each of the 18 animals that received $10 \mu \mathrm{g}$ of morphine into $\mathrm{SNr}$. On the basis of these counts, subjects were placed into a "medial" group (greatest number of cells in area 1 and no cells in area 4), a "lateral" group (greatest number of cells in area 2), or a "mediolateral" group (greatest number of cells in areas 1 and 2, with cells in areas 3 and 4). Plots of the numbers of cells in each region of striatum for each group are shown in Figure $6 A$. Note the progressive decrease in cells in area 1 going from medial to lateral and the progressive increase in cells in areas 2,3 , and 4 going from medial to lateral.

After the subdivision of these animals into the three groups based on the Fos-staining pattern in striatum, a histological analysis of the $10 \mu \mathrm{g}$ morphine injection sites in $\mathrm{SNr}$ was performed. These sites were plotted in Figure $7 A$. Animals from the medial group had SNr injection sites located in the medial third of the SNr; subjects from the lateral group had $\mathrm{SNr}$ injection sites located in the lateral third of the $\mathrm{SNr}$; and subjects from the mediolateral group had SNr injection sites located in the middle third of SNr. On the basis of this observation, the SNr was divided into three equal sectors (dotted lines shown in Fig. 7A) and labeled the medial, middle, and lateral sectors of SNr. Using this subdi- 
A

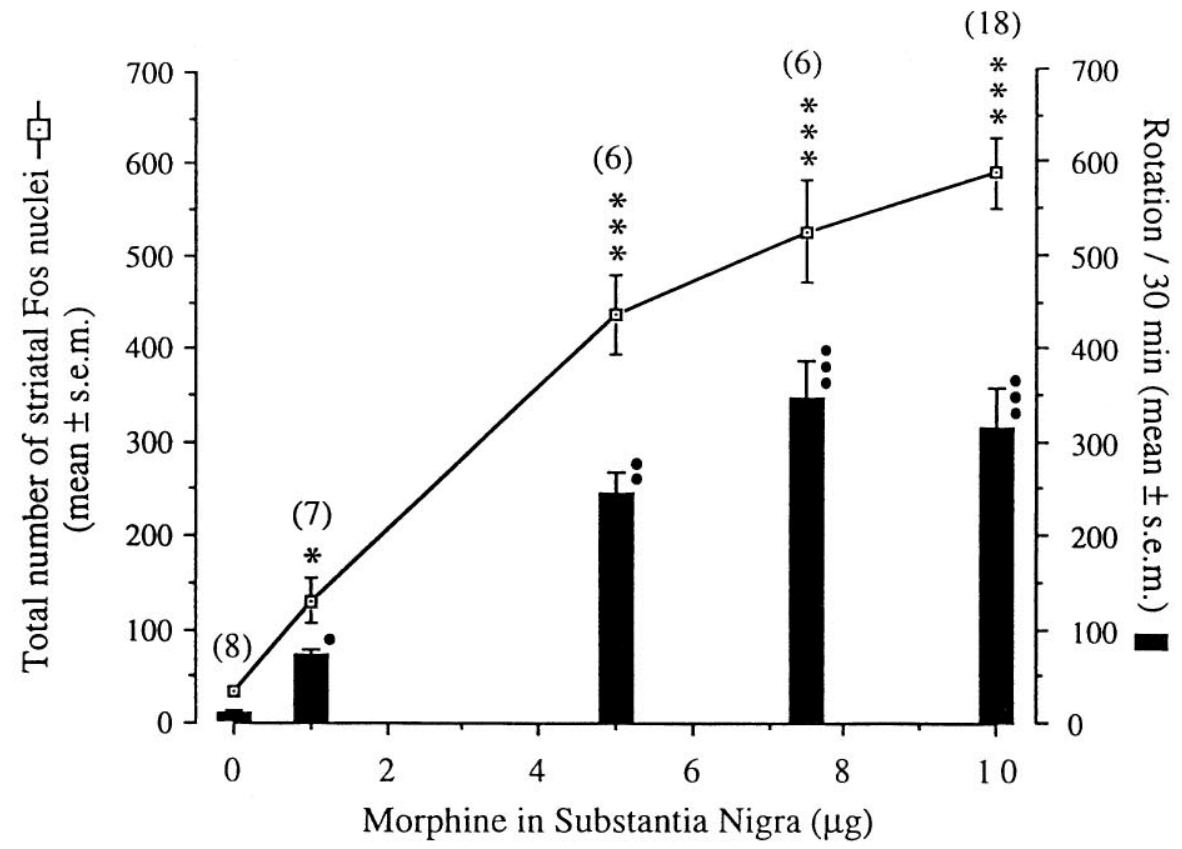

B
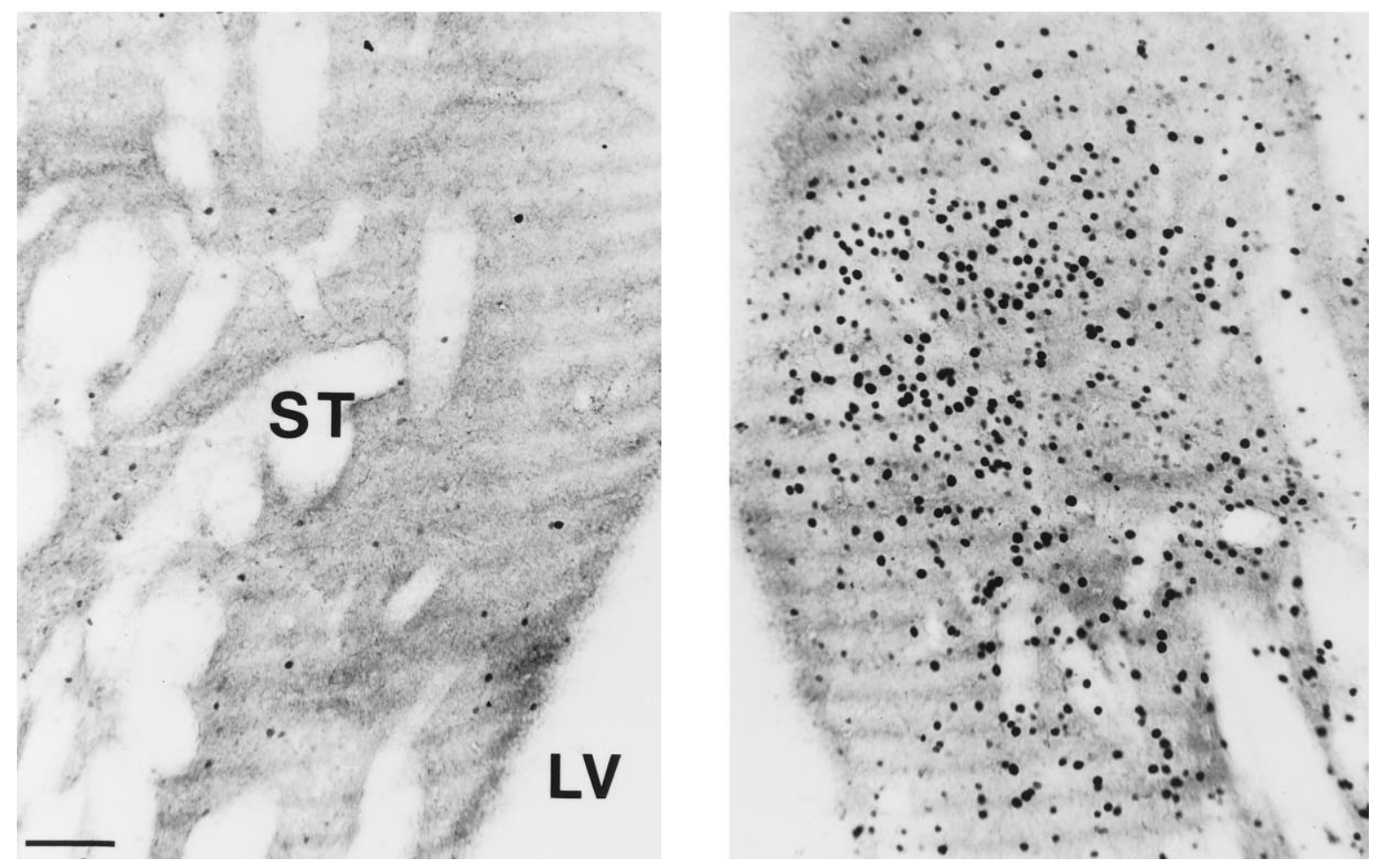

Figure 3. A, Number of Fos-immunoreactive nuclei (open squares) induced in the rat striatum $2 \mathrm{hr}$ after saline $(0)$ and morphine injections $(1,5,7.5$, and $10 \mu \mathrm{g}$ in $0.5 \mu \mathrm{l}$ ) into ipsilateral substantia nigra pars reticulata $(\mathrm{SNr})$ and the effects of each dose of morphine on rotational behavior $($ filled bars). Note that increasing morphine doses increased the number of Fos-stained neurons in striatum, the maximal response being obtained with $10 \mu \mathrm{g}$ of morphine. Morphine injections were accompanied by a dose-dependent increase in locomotor activity as revealed by the number of rotations recorded during the first 30 min after morphine injections. Animals rotated away from the injection side (contralateral turning). The number of rats in each group is given in parentheses. Fos induction: ${ }^{*} p<0.05$; ${ }^{* * *} p<0.001$ as compared with saline (0 dose). Rotation: ${ }^{\bullet} p<0.05 ;{ }^{\bullet \bullet} p<0.01 ;{ }^{\bullet \bullet \bullet} p<0.001$ as compared with saline. $B$, Photomicrographs of a rat striatum (dorsomedial part) showing Fos protein induction $2 \mathrm{hr}$ after saline injection into one medial SNr (left) and morphine injection $(10 \mu \mathrm{g})$ into the opposite medial SNr $(r i g h t)$ of the same animal. Note that the intranigral injection of morphine markedly increased Fos protein in dorsomedial striatum (right) as compared with the side injected with saline (left). ST, Striatum; $L V$, lateral ventricle. Scale bar, $100 \mu \mathrm{m}$. 


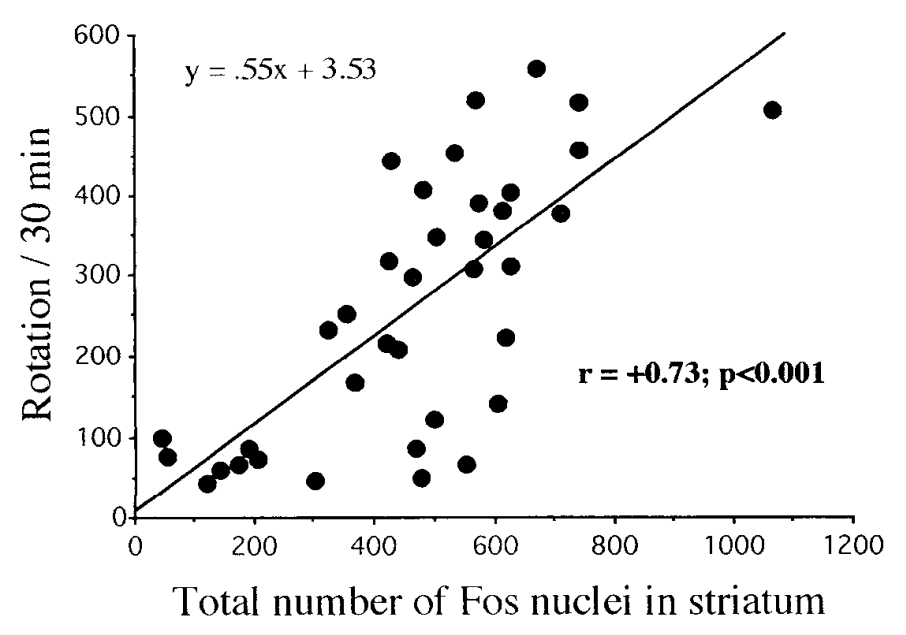

Figure 4. Plot of the rotation rate recorded during the first $30 \mathrm{~min}$ after intranigral injections of morphine $(1,5,7.5$, and $10 \mu \mathrm{g} ; n=37)$ versus the total number of Fos-positive nuclei counted in the striatum. The rotational behavior was positively correlated with the number of striatal Fos neurons $(r=+0.73 ; p<0.001$; df $=36)$. The line represents linear regression derived by the method of least squares.

vision of the SNr, a two-factor repeated ANOVA showed that the number of Fos nuclei in the different areas of the striatum (areas $1-4$, Fig. $1 B$ ) was a function of the $\mathrm{SNr}$ sector (medial, middle, and lateral) infused with morphine $\left(F_{(6,45)}=30.99 ; p<0.001\right)$. A similar analysis performed on all the animals infused with 1,5 , 7.5 , and $10 \mu \mathrm{g}$ of morphine into SNr confirmed this result $\left(F_{(6,102)}\right.$ $=11.38 ; p<0.001)$ and also revealed that within each area of the striatum, the number of Fos-positive neurons was a function of the dose of morphine injected into a given sector of $\operatorname{SNr}\left(F_{(4,69)}\right.$ $=126.39 ; p<0.001)$. Figure $3 A$ shows the general morphineinduced dose-dependent increase in striatal Fos nuclei regardless of the injection sites in SNr. Although our experimental approach was not designed to target specific $\mathrm{SNr}$ sectors, a detailed analysis revealed that the lowest dose of morphine $(1 \mu \mathrm{g})$ was more effective in inducing Fos in striatum when injected in medial $\mathrm{SNr}$ than in lateral SNr. This may suggest that a difference in responsivity to morphine exists in SNr.

These findings are consistent with neuroanatomical data showing that dopamine projections from $\mathrm{SN}$ to striatum are topographically organized (Fallon and Moore, 1978). Despite an eventual diffusion factor associated with the drug used, the data indicate that receptors located close to the injection site are directly involved in the morphine-induced behavioral and biochemical effects (David and Cazala, 1994). To confirm the specificity of the different patterns of Fos expression, four animals were injected with $10 \mu \mathrm{g}$ of morphine into a "negative control" site that was $2 \mathrm{~mm}$ dorsal to the $\mathrm{SNr}$ (Fig. 7A, filled squares). These injections did not induce any Fos in striatum nor did they produce any rotational behavior. The anterior-posterior placement of the injection cannula (between 5.2 and $6.0 \mathrm{~mm}$ posterior to bregma; Fig. $1 A$ ) did not seem to be of major importance in determining either the pattern of Fos expression within the striatum or the rate of turning. Although the anterior to posterior distribution of Fos-stained cells in striatum was not analyzed quantitatively, there were relatively fewer Fos-immunoreactive neurons in anterior striatum than in middle striatum, especially after morphine injections into the middle and lateral SNr. The anterior to posterior distribution of Fos-stained cells in the striatum was globally similar to that observed after intraperitoneal injections of morphine $(10 \mathrm{mg} / \mathrm{kg})$. Systemic morphine also induced Fos protein in medial prefrontal, cingulate, and parietal cortices, as well as in centromedial and centrolateral thalamic nuclei (not shown). This pattern of Fos induction was globally mimicked by morphine injections into medial $\mathrm{SNr}$ (Fig. 8). Although smaller and less consistent responses were observed in thalamic nuclei, this suggests that the activation of an "SNthalamo-cortical" circuit may mediate Fos induction in cortical areas that in turn would activate specific sets of striatal neurons.

In preliminary experiments, the fluorescent tracer Fluoro-Gold ( $0.5 \mu$ l of a $3 \%$ solution) was injected into $\mathrm{SNr}$ to retrogradely label striatonigral neurons. Five days later, morphine was administered systemically, and Fos expression in striatum was examined $2 \mathrm{hr}$ later. Fos was expressed in striatal neurons labeled with Fluoro-Gold as reported by Cenci et al. (1992). This result suggests that Fos is expressed, at least in part, in striatal neurons that project to $\mathrm{SN}$, contain substance $\mathrm{P}$, and are proposed to have $\mathrm{D}_{1}$ receptors (Gerfen et al., 1990; Robertson et al., 1990; Gerfen, 1992; Kosofsky et al., 1995; Surmeier et al., 1996). Recent studies suggest that substance P-containing striatal neurons, expressing $\mathrm{D}_{1 \mathrm{a}}, \mathrm{D}_{3}$, and $\mathrm{D}_{4}$ receptors, project to the $\mathrm{SN}$ and internal and external segments of GP. Substance P and enkephalin neurons, which make up a small percentage of striatal neurons and contain $\mathrm{D}_{1 \mathrm{a}}$ and $\mathrm{D}_{2}$ receptors, project to the same locations (Surmeier et al., 1996).

\section{Relationship between rotational behavior and Fos staining in the different areas of the striatum}

Figure $6 A$ presents the number of Fos-positive nuclei in the different areas of the striatum for the three groups (medial, mediolateral, and lateral) of animals injected with $10 \mu \mathrm{g}$ of morphine into the different sectors of $\mathrm{SNr}$ and compares this number with the rotational behavior observed for these groups. A one-way ANOVA revealed a significant effect of Fos pattern on rotational behavior $\left(F_{(2,15)}=54.35 ; p<0.001\right)$. The greatest rotation rate was observed in the lateral pattern group, which also showed a peak of Fos-stained cells in area 2 of the striatum. The lowest rotation rate was observed in the medial pattern group, in which most of the Fos-positive neurons were located in area 1, the most dorsomedial portion of striatum.

The numbers of Fos-stained neurons in the specific areas of striatum were found to correlate with the rotational behavior (Fig. 6B). The number of rotations was highly positively correlated with the number of Fos-positive nuclei in area $2(r=+0.89$; $\left.F_{(1,16)}=58.69 ; p<0.001\right)$. For area 1 , however, the rate of rotation was negatively correlated with the number of Fos-stained cells $\left(r=-0.77 ; F_{(1,16)}=23.65 ; p<0.001\right)$. That is, animals with greater numbers of Fos-stained cells in area 2 rotated at faster rates, whereas animals with greater numbers of Fos-stained cells in area 1 rotated at slower rates (Fig. 6B). Similar results were obtained when all the animals injected with all doses of morphine $(1,5,7.5$, and $10 \mu \mathrm{g})$ into $\mathrm{SNr}$ were combined. Significant positive correlations were found when using areas 2,3 , or 4 separately or all three areas together $\left(r=+0.86 ; F_{(1,35)}=101.61 ; p<0.001\right)$, the highest correlation being found in area 2 of the striatum $(r=$ $\left.+0.88 ; F_{(1,35)}=125.73 ; p<0.001\right)$.

The lateral pattern group of animals injected with $10 \mu \mathrm{g}$ of morphine into the lateral $\mathrm{SNr}$ not only expressed Fos in dorsolateral parts of the striatum but also had a large number of Fos-positive neurons in the GP (Fig. 9A, Table 1). In contrast, very few Fos-positive neurons were observed in the GP in the medial pattern group, in which the rotation rate was the lowest 

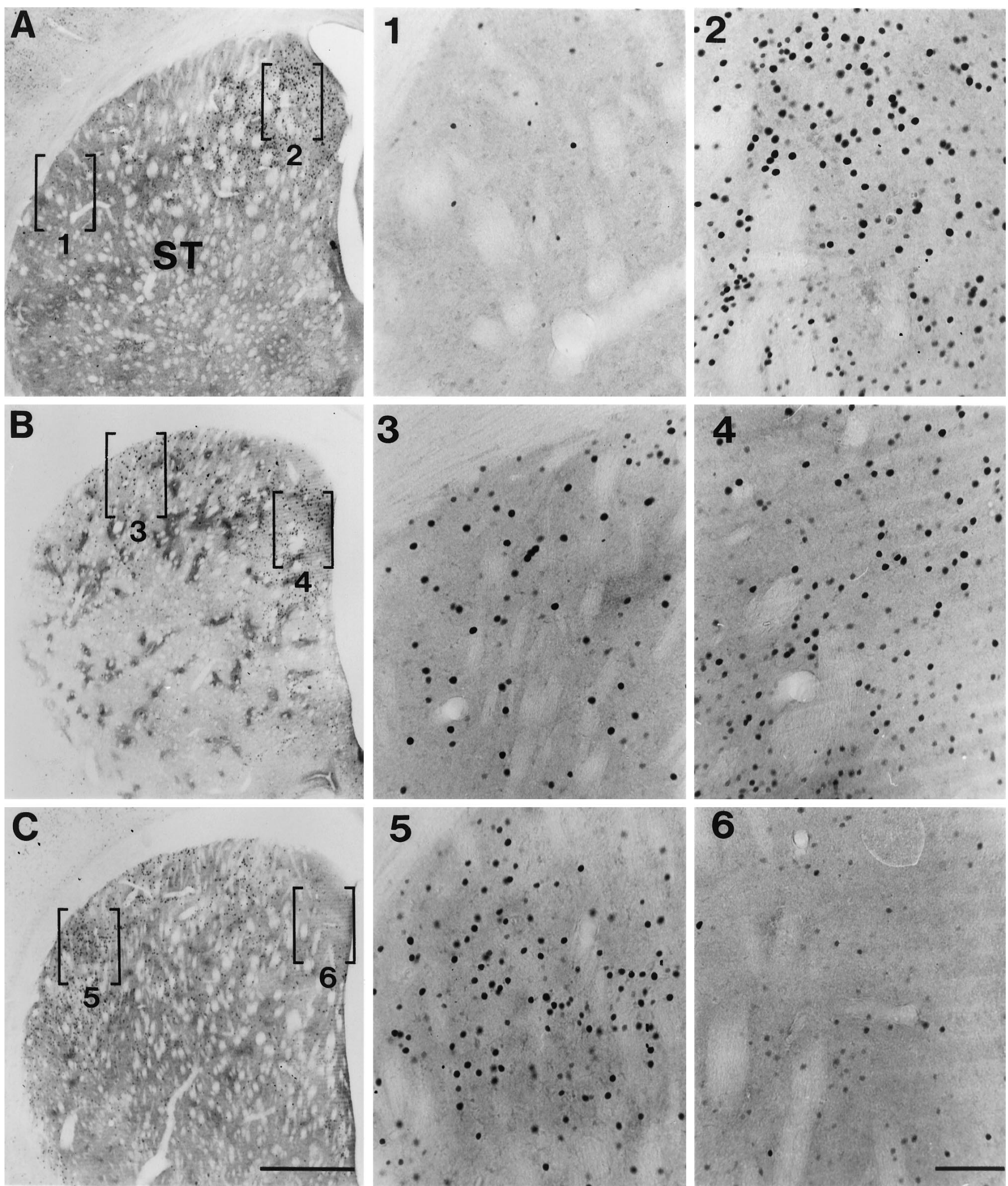

Figure 5. Photomicrographs illustrating the distribution of Fos-positive nuclei in the striatum $2 \mathrm{hr}$ after ipsilateral injections of morphine (10 $\mu \mathrm{g})$ into the medial part $(A)$, the middle part $(B)$, or the lateral part $(C)$ of the $\mathrm{SNr}$ (for injection site placements, see Fig. $7 A$ ). Fields indicated by brackets are shown at higher magnification in panels 1-6. An intense induction of Fos was observed in the dorsomedial striatum $(A 2)$ after morphine injection into medial SNr, whereas very few Fos-positive neurons were found in the dorsolateral striatum $(A 1)$. After morphine injections into the middle SNr, Fos was expressed in both dorsomedial (B4) and dorsolateral striatum (B3). After morphine injections into lateral SNr, Fos-stained neurons were mainly limited to the dorsolateral striatum (C5), with little Fos in the dorsomedial striatum (C6). ST, Striatum. Scale bars: $A-C, 1 \mathrm{~mm}$; panels $1-6,150 \mu \mathrm{m}$. 


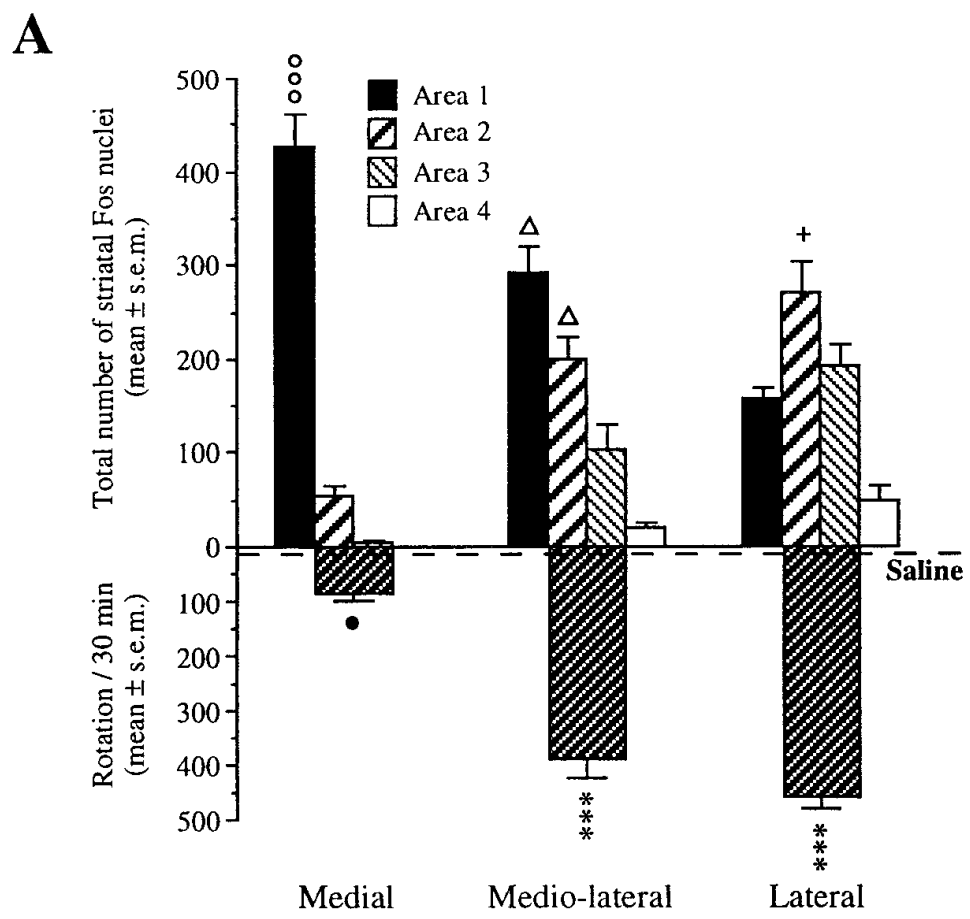

B
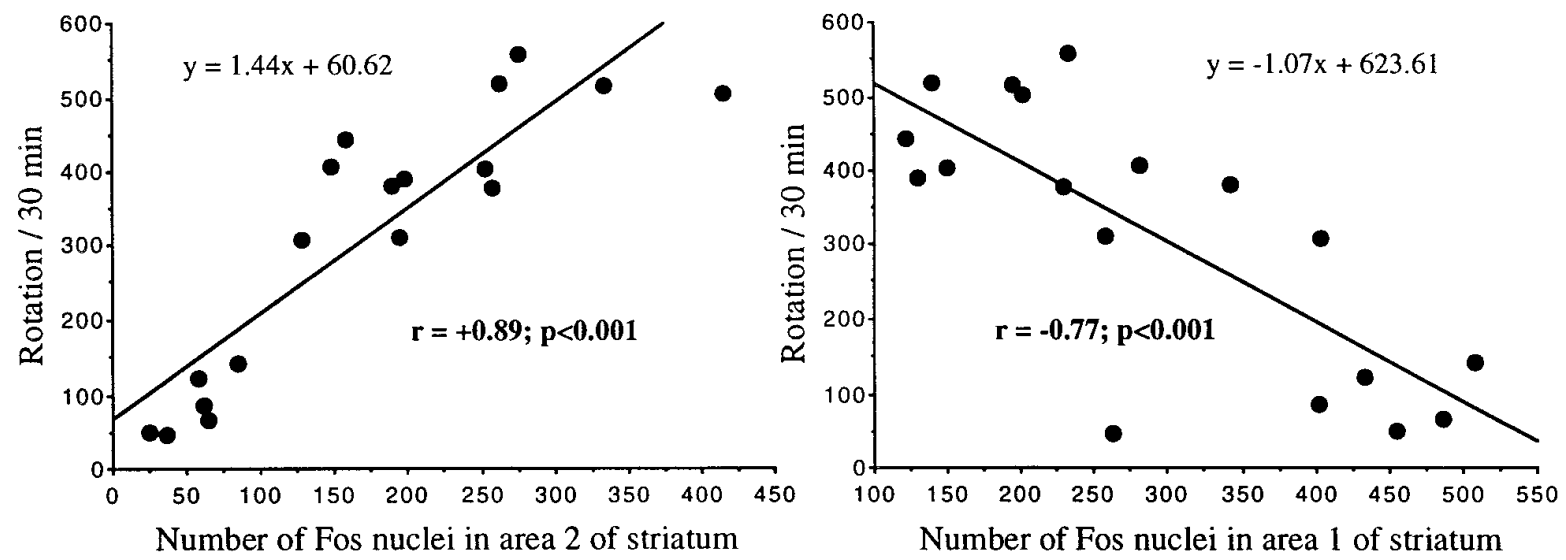

Figure 6. Effects of intranigral morphine injections on the distribution of Fos immunostaining within the striatum and on the rotational behavior. $A$, Animals injected with $10 \mu \mathrm{g}$ of morphine were divided into three groups (Medial pattern group, $n=6$; Medio-lateral pattern group, $n=6$; and Lateral pattern group, $n=6$ ) according to the patterns of Fos expression in the four different areas of the striatum (areas 1, 2, 3, and 4; see Fig. 1B). The number of Fos-positive neurons in the different areas of the striatum for these three groups is presented with the corresponding rotational behavior. Rotation rate was greater in the lateral and mediolateral groups compared with the medial and saline (dotted line) groups $(\bullet p<0.05$ as compared with saline group; ${ }^{* *} p<0.001$ as compared with medial and saline groups). Fos induction was the greatest in area 1 in the medial group and declined in the other groups, whereas the numbers of Fos-stained cells increased in areas 2,3, and 4 in the lateral group compared with the medial group. (Medial group, ${ }^{\circ 0} p<$ 0.001 for area 1 as compared with areas 2, 3, and 4. Medio-lateral group, ${ }^{\Delta} p<0.05$ for areas 1 and 2 as compared with areas 3 and 4 . Lateral group, ${ }^{+} p<$ 0.05 for area 2 as compared with areas 1,3 , and 4$). B$, The magnitude of the morphine-induced rotational behavior correlated with the pattern of Fos expression within the striatum. The number of rotations was positively correlated (left panel) with the number of Fos-positive nuclei in area 2 of striatum $(r=+0.89 ; p<0.001 ; \mathrm{df}=17)$ but was negatively correlated (right panel) with the number of Fos-stained neurons in area 1 of striatum $(r=-0.77$; $p<0.001 ; \mathrm{df}=17)$.

(Fig. 9B, Table 1). Linear regression analysis performed on the 18 animals injected with $10 \mu \mathrm{g}$ of morphine confirmed that the total number of Fos-positive nuclei in the ipsilateral GP was significantly and positively correlated with the rotational behavior $(r=$ $\left.+0.77 ; F_{(1,16)}=23.55 ; p<0.001\right)$. A similar correlation between rates of rotation and numbers of Fos-stained nuclei in GP was found when all the animals injected with the different doses of morphine into SNr were combined $\left(r=+0.80 ; F_{(1,35)}=60.95\right.$; $p<0.001)$.

\section{Effects of SNr injections of $\mu$ opioid agonist and GABA $_{A}$ antagonist}

To confirm that morphine induction of Fos in striatum was caused by specific actions on $\mu$ opioid receptors, the $\mu$-specific agonist 
Figure 7. Locations of injection cannula tips for animals that received morphine either $(A)$ into the substantia nigra pars reticulata $(S N R)(10 \mu \mathrm{g}$ in $0.5 \mu \mathrm{l})$ or $(B)$ into the ventral tegmental area (VTA) $(10$ $\mu \mathrm{g}$ in $0.3 \mu \mathrm{l})$. All injection sites, which were between 5.2 and $6.0 \mathrm{~mm}$ posterior to bregma for $\mathrm{SNr}$ and between 4.8 and $5.6 \mathrm{~mm}$ posterior to bregma for VTA, are represented on two single planes $(-5.6$ and $-5.2 \mathrm{~mm}$ for $\mathrm{SNr}$ and VTA, respectively) (redrawn from Paxinos and Watson, 1986). The $\mathrm{SNr}$ was arbitrarily divided into three regions shown with the dotted lines and labeled MEDIAL, MID$D L E$, and LATERAL. The symbols denote injection sites within $\mathrm{SNr}$, and the type of symbol denotes whether the injection induced Fos in medial striatum/NAc ( filled triangles), in medial and lateral striatum (open circles), or mainly in lateral striatum (filled circles) (see Fig. 5). The symbols above the $\mathrm{SNr}$ (filled squares) represent a "negative control site" made to test the site specificity. These morphine injections did not induce Fos in striatum nor did they produce rotational behavior. Morphine injections into the VTA $(B)$ were found to induce Fos protein mostly in NAc and medial striatum (see Fig. 13) (for complete listing of all abbreviations, see Paxinos and Watson, 1986).
A

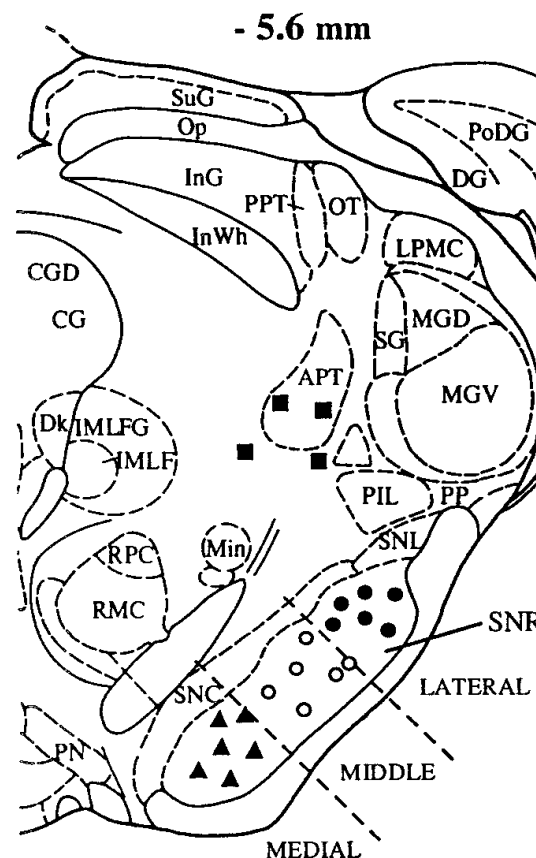

B

\section{$-5.2 \mathrm{~mm}$}

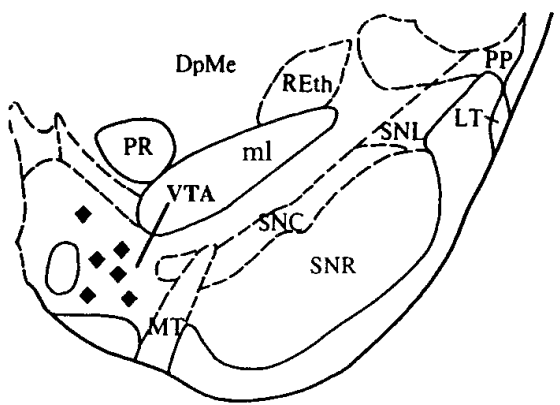

- Fos in NAc and medial striatum
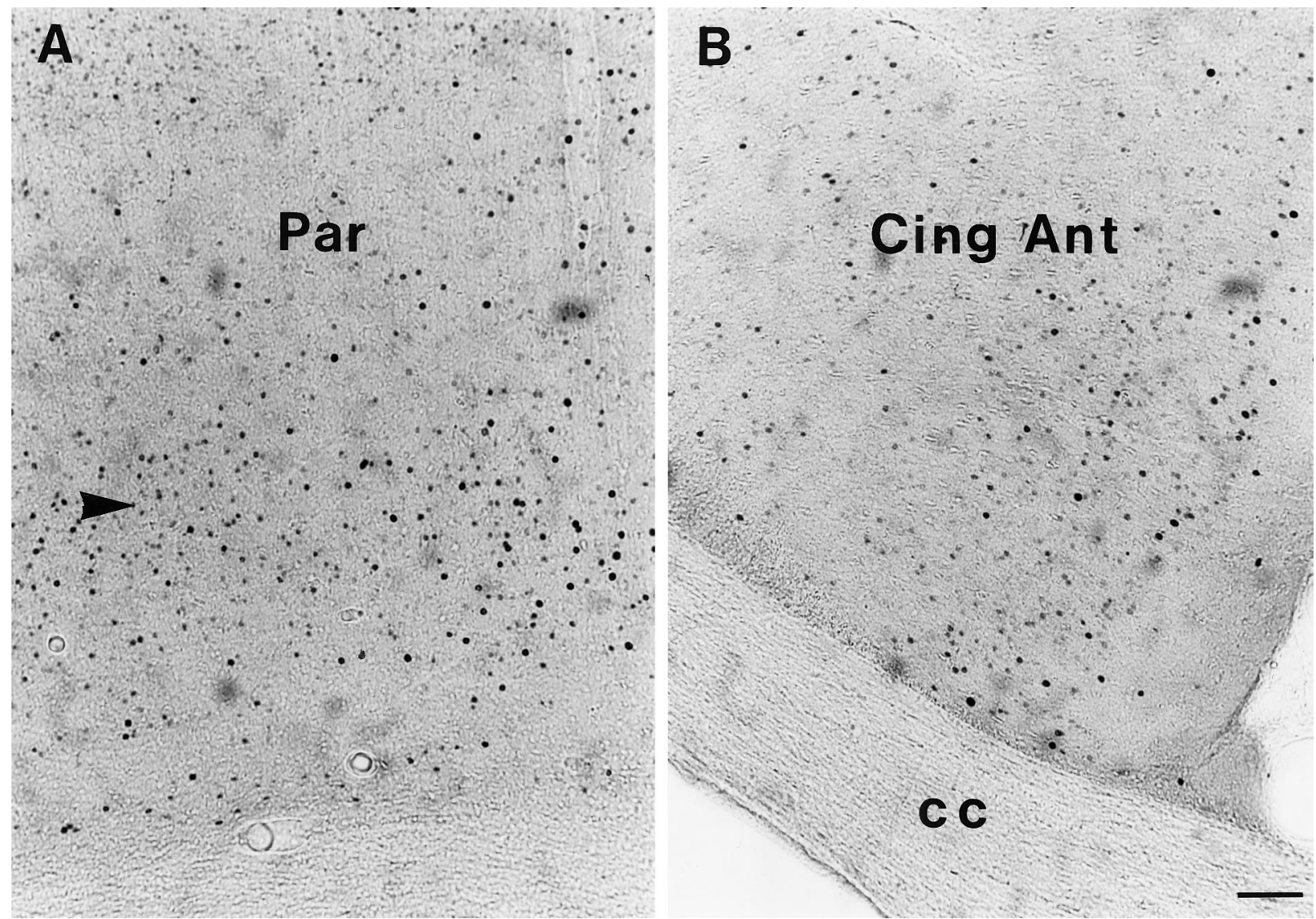

Figure 8. Photomicrographs of Fos immunoreactivity in coronal sections through the parietal $(A)$ and anterior cingulate $(B)$ cortices showing marked induction of Fos-positive nuclei in a rat injected with $10 \mu \mathrm{g}$ of morphine into the medial part of the SNr. Note the large number of cells immunoreactive for Fos in parietal cortex, especially in layer VI (arrowhead). Par, Parietal cortex; Cing Ant, anterior cingulate cortex; cc, corpus callosum. Scale bar, $80 \mu \mathrm{m}$. 

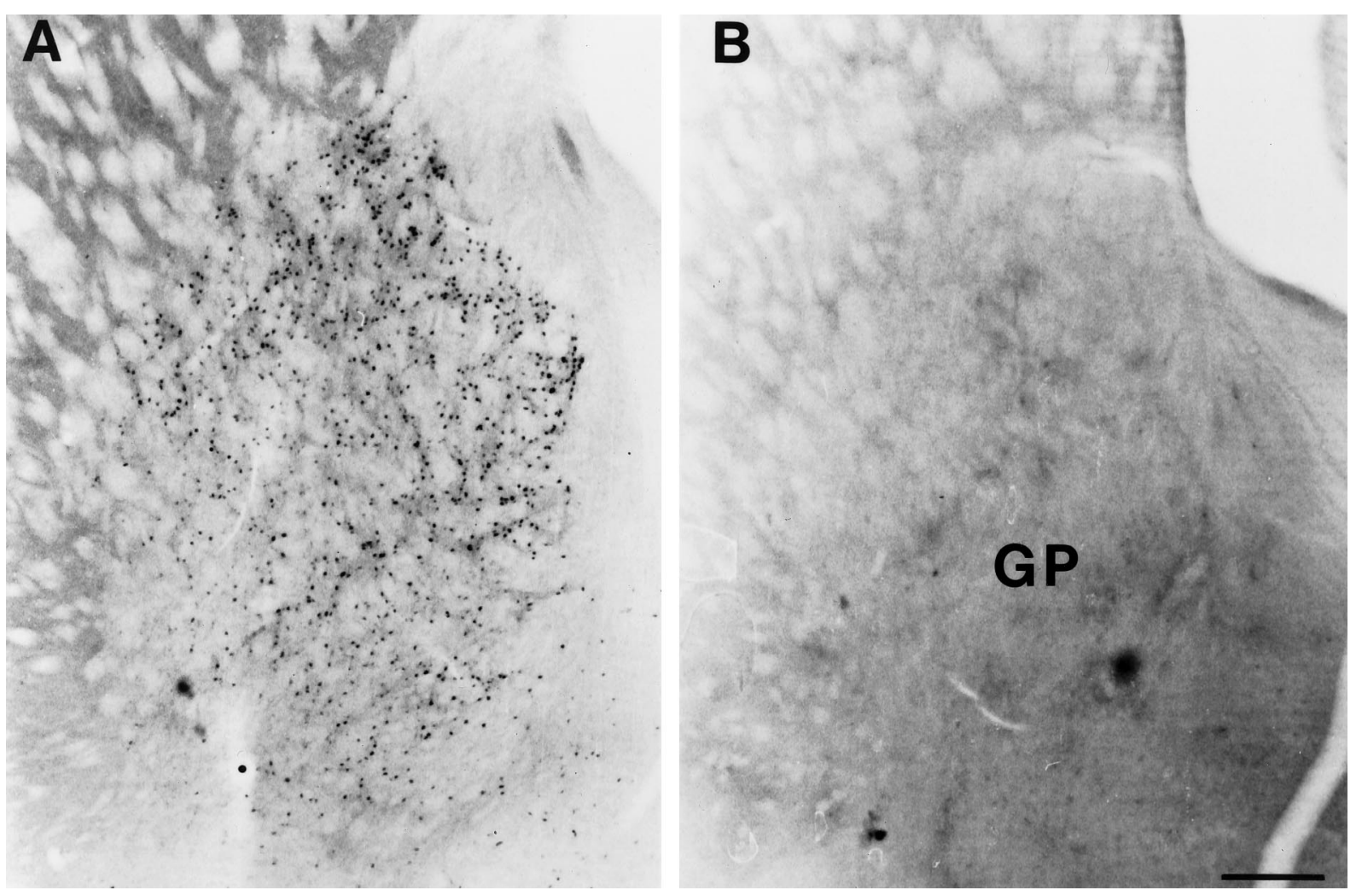

Figure 9. Photomicrographs of Fos immunoreactivity in coronal sections through the globus pallidus $(G P)$ showing $(A)$ marked induction of Fos-positive nuclei in a rat injected with $10 \mu \mathrm{g}$ of morphine into the lateral part of the SNr compared with $(B)$ no Fos immunostaining in a rat injected with $10 \mu \mathrm{g}$ of morphine into the medial part of the SNr. Scale bar, $300 \mu \mathrm{m}$.

Table 1. Number of Fos-positive nuclei in striatum, NAc, and GP after morphine injections either into VTA or into $\mathrm{SNr}$

\begin{tabular}{|c|c|c|c|c|}
\hline \multirow[b]{2}{*}{ Brain region } & \multicolumn{4}{|c|}{ Morphine $10 \mu \mathrm{g}$} \\
\hline & VTA & Medial SNr & Middle SNr & Lateral SNr \\
\hline \multicolumn{5}{|l|}{ Striatum } \\
\hline Area 1 & $256.7 \pm 43.2^{* * *}$ & $425.0 \pm 35.8$ & $291.4 \pm 28.1$ & $155.7 \pm 13.6$ \\
\hline Area 2 & $32.7 \pm 7.4$ & $55.3 \pm 8.9$ & $198.8 \pm 22.8$ & $270.0 \pm 33.1^{*}$ \\
\hline Area 3 & $0.3 \pm 0.3$ & $4.3 \pm 1.8$ & $102.9 \pm 27.8$ & $192.2 \pm 28.6$ \\
\hline Area 4 & $0.0 \pm 0.0$ & $0.0 \pm 0.0$ & $19.6 \pm 6.8$ & $50.5 \pm 13.2$ \\
\hline NAc & $205.0 \pm 17.9^{* * *}$ & $94.0 \pm 15.0$ & $57.2 \pm 5.2$ & $19.1 \pm 2.5$ \\
\hline GP & $47.3 \pm 12.0$ & $12.5 \pm 3.8$ & $142.3 \pm 30.7$ & $323.0 \pm 28.3^{* *}$ \\
\hline
\end{tabular}

Data are mean \pm SEM. Injections of morphine into VTA induced Fos predominantly in area 1 of striatum and NAc $(* * * p<$ 0.001 as compared with the remaining four brain regions). Morphine injected into the lateral part of SNr induced Fos predominantly in GP $(* * p<0.01)$ and area 2 of striatum $(* p<0.05)$. For further comparisons of Fos induction within the striatum (areas 1-4) after morphine injections into medial, middle, and lateral SNr, see Figure $6 \mathrm{~A}$.

DAMGO was injected into the SNr. Depending on the location of the injection site within the $\mathrm{SNr}$, contralateral rotational behavior was obtained with doses varying from 0.1 to $5 \mu \mathrm{g}$ (data not shown). The $1 \mu \mathrm{g}$ dose of DAMGO injected into $\mathrm{SNr}$ induced numbers of Fos-positive neurons in striatum (Figs. 10B, 11 $A$ ) similar to those induced by the 5-10 $\mu \mathrm{g}$ doses of morphine (Fig. $3 A$ ). In addition, intranigral injections of DAMGO induced numbers of Fos-stained neurons in striatum (Fig. 10B) similar to those induced by systemic injections of morphine (Fig. $10 \mathrm{~A}$, open bars). The injection of the $\mathrm{GABA}_{\mathrm{A}}$ antagonist bicuculline (doses varying from 0.05 to $1 \mu \mathrm{g}$ ) into the $\mathrm{SNr}$ also induced Fos in striatum
(Figs. $10 B, 11 E ; 0.5 \mu \mathrm{g}$ dose) and produced contralateral turning (data not shown). The saline injections into $\mathrm{SNr}$ of the same animals induced few Fos-positive nuclei in striatum (Figs. $10 B, 11 B, F)$.

\section{Effects of $\mu_{1}, D_{1}$, and NMDA receptor antagonists on systemic morphine-induced Fos immunoreactivity}

To further define the role of $\mu$ opioid receptors in $\mathrm{SNr}$, the $\mu_{1}$ receptor antagonist naloxonazine was injected into the $\mathrm{SNr}$ with the same volume of vehicle infused into the opposite SNr. Systemic morphine injected 30 min later markedly induced Fos in 
Figure 10. $A$, Effects of injection of the $\mu_{1}$ opioid receptor antagonist naloxonazine $(N L X Z)$ into substantia nigra pars reticulata $(S N r)$ and ventral tegmental area $(V T A)$ or intrastriatal injections of the NMDA glutamate receptor antagonist MK 801 and the $\mathrm{D}_{1}$ dopamine receptor antagonist SCH 23390 on Fos induction in striatum $(S T)$ after systemic administration of morphine $(10 \mathrm{mg} / \mathrm{kg}$, i.p., 4 times over $2 \mathrm{hr})$. The different antagonists were injected 30 min before morphine. The number of Fospositive nuclei was significantly reduced $\left({ }^{* *} p<0.01 ;{ }^{* * *} p<0.001\right)$ in the striatum ipsilateral to the antagonist injections (cross-hatched bars) compared with vehicle injections (open bars). B, The $\mu$ opioid receptor agonist DAMGO and the $\mathrm{GABA}_{\mathrm{A}}$ receptor antagonist bicuculline injected into $\mathrm{SNr}$ significantly increased $\left({ }^{* * *} p<\right.$ 0.001 ) the number of Fos-positive nuclei in the striatum ipsilateral to the injected side (cross-hatched bars) compared with the vehicle-injected side (open bars).
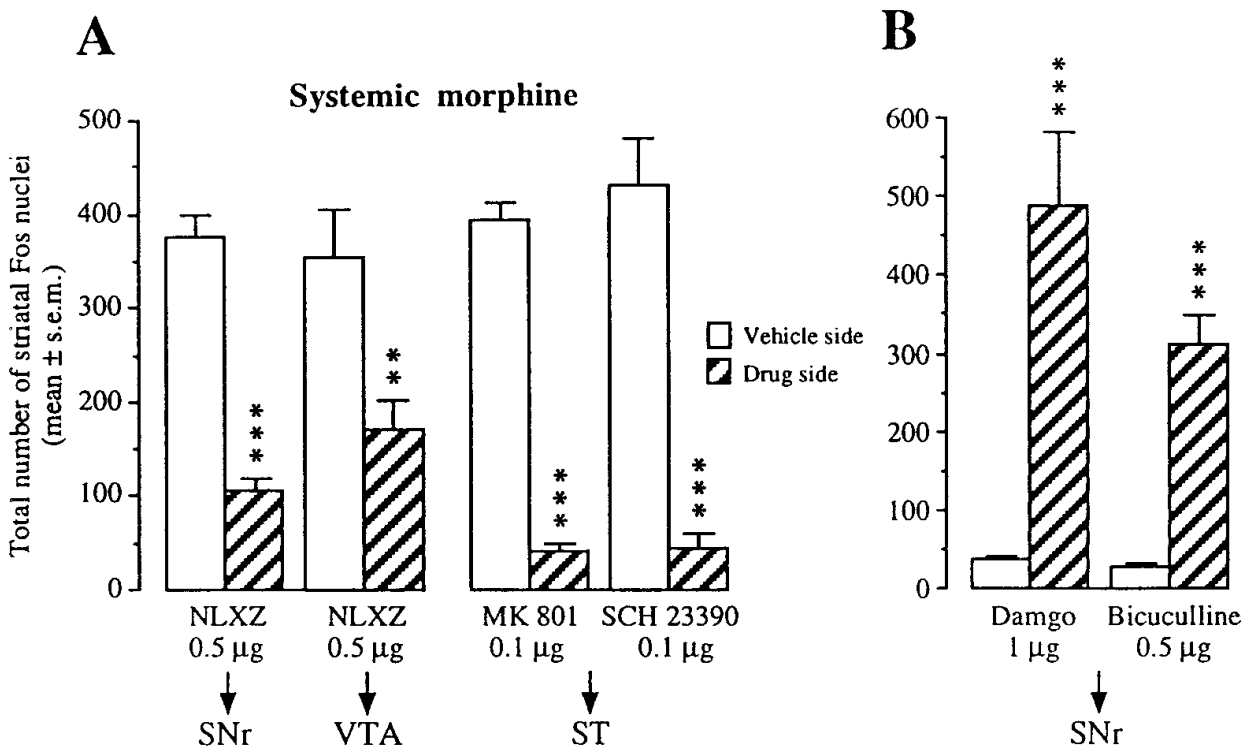

medial striatum ipsilateral to the vehicle injection into SNr (Figs. $10 A, 11 D)$, whereas Fos induction was markedly suppressed but not completely blocked in medial striatum ipsilateral to the naloxonazine injection (Figs. $10 \mathrm{~A}, 11 \mathrm{C}$ ). Similar results were obtained when naloxonazine was injected into the VTA before systemic morphine (Fig. 10A). Animals injected with naloxonazine alone into SNr or VTA did not show any significant Fospositive nuclei in striatum (not shown).

One experiment was not performed in animals that received systemic morphine. Injection of bicuculline, a $\mathrm{GABA}_{\mathrm{A}}$ antagonist, into $\mathrm{SNr}$ induced Fos in striatum, as described previously in Results. On the basis of this finding, we would predict that injection of a $\mathrm{GABA}_{\mathrm{A}}$ agonist into $\mathrm{SNr}$ should block Fos induction in striatum produced by systemic administration of morphine. In preliminary experiments, we found that although no Fos induction was observed after intrategmental injections of muscimol, intranigral injections unexpectedly induced Fos in striatum. This result indicates that Fos induction is mediated by a complex circuitry in the VTA and SN. The stimulation of nigrostriatal neurons by a $\mathrm{GABA}_{\mathrm{A}}$ agonist suggests that a second inhibitory interneuron located in SN may participate in the GABAergic regulation of nigrostriatal neurons (Westerink et al., 1996).

MK 801 and SCH 23390 were injected into striatum on one side of the brain, and vehicle was injected into the other side (Figs. $10 \mathrm{~A}, 12)$. After systemic injections of morphine, large numbers of Fos-immunostained neurons were induced in medial striatum ipsilateral to the vehicle injections (Figs. $10 A, 12 B, D$ ), whereas Fos induction was almost completely blocked in the medial striatum ipsilateral to the MK 801 or SCH 23390 infusions (Figs. $10 A, 12 A, C)$. Animals injected with MK 801 or SCH 23390 alone did not show any significant Fos-positive nuclei in striatum (not shown).

\section{Effects of morphine injections into VTA on Fos immunoreactivity in striatum and NAC}

Injections of $10 \mu \mathrm{g}$ of morphine into the VTA produced contralateral turning (data not shown) and a significant increase in the number of Fos-immunoreactive neurons in the ipsilateral striatum (Fig. 13A) compared with the saline control-injected side. The Fos-stained cells were located mainly in the dorsomedial and ventromedial portions of the striatum (Fig. 13A), whereas fewer Fos-positive cells were located in lateral striatum compared with the SNr injections (Table 1). The greatest difference between SNr and VTA injections of morphine was noted in NAc, where Fos was markedly induced after VTA injections (Fig. 13B, Table 1) but not after injections into the lateral part of SNr (Fig. $13 D$, Table 1). Morphine injections into medial SNr induced Fos in NAc, but to a lesser extent than VTA injections (Fig. 13C, Table 1). Separate counts in the core and shell regions of NAc were not performed to compare SNr and VTA injections.

\section{DISCUSSION}

\section{$\mu$ opioid receptors in SNr and VTA mediate morphine- induced Fos protein in striatum and NAC}

Systemic morphine induces Fos protein in limbic portions of striatum and NAc (Chang et al., 1988; Liu et al., 1994), a response blocked by systemic $\mu$ opioid receptor antagonists (Bontempi et al., 1995; Garcia et al., 1995). This study determined where systemic morphine acts and which receptors are responsible for Fos induction. Morphine action on $\mu$ opioid receptors in $\mathrm{SNr}$ and VTA is sufficient to induce Fos in striatum and NAc because (1) morphine injections into $\mathrm{SNr}$ induce Fos in striatum, (2) morphine injections into VTA induce Fos in NAc and dorsomedial striatum, (3) Fos is expressed in striatum after intranigral injection of the $\mu$ opioid receptor agonist DAMGO, and (4) $\mathrm{SNr}$ and VTA injections of the $\mu_{1}$ opioid receptor antagonist naloxonazine block Fos induction in medial striatum produced by systemic morphine.

Morphine infusions into $\mathrm{SNr} / \mathrm{VTA}$ should act on $\mu$ opioid receptors. The $\mu$ receptors are not located on SNc/VTA dopamine neurons because $\mu$ receptors are coupled to inhibitory guanine nucleotide binding proteins (Laugwitz et al., 1992) that inhibit neurons. Morphine, however, increases SNc/VTA dopamine neuronal firing (Matthews and German, 1984; Di Chiara and Imperato, 1988a; Johnson and North, 1992; Devine et al., 1993; Devine and Wise, 1994). Morphine could act on $\mu$ receptors located on GABAergic interneurons in SNr and VTA (Di Chiara and North, 1992; Johnson and North, 1992). Morphine binding to $\mu$ receptors located on $\mathrm{SNr} / \mathrm{VTA}$ GABA interneurons would inhibit these cells, decrease GABA release, and decrease tonic inhibition of SNc/VTA dopamine neurons. Increased firing of 

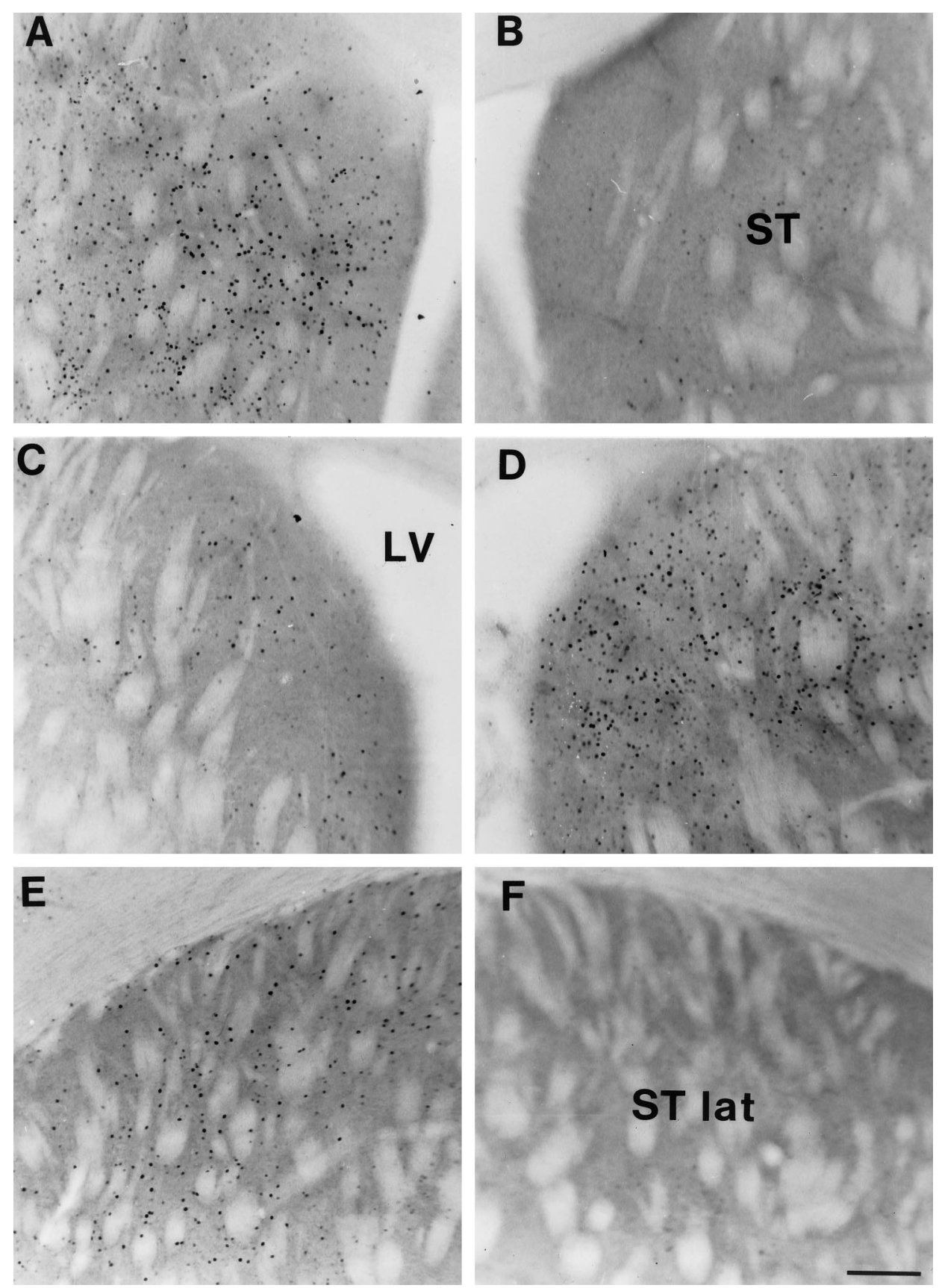

Figure 11. $A, B$, Photomicrographs of a rat dorsomedial striatum showing $(A)$ marked Fos protein induction $2 \mathrm{hr}$ after injection of the $\mu$ opioid receptor agonist DAMGO (1 $\mu \mathrm{g})$ into one medial $\mathrm{SNr}$ as compared with $(B)$ the very low level of Fos induction after saline injection into the opposite medial $\mathrm{SNr}$. $C, D$, Fos protein induction in dorsomedial striatum after systemic administration of morphine $(10 \mathrm{mg} / \mathrm{kg}$, i.p., 4 times over $2 \mathrm{hr}$ ) in a rat that had vehicle injected into one $\mathrm{SNr}$ (D) and the $\mu_{1}$ opioid receptor antagonist naloxonazine $(0.5 \mu \mathrm{g})$ injected into the opposite $\mathrm{SNr}(C) 30 \mathrm{~min}$ previously. Note that Fos induction was reduced in the striatum ipsilateral to the naloxonazine injection. $E$, $F$, Fos protein induction in the dorsolateral striatum of an animal injected with the $\mathrm{GABA}_{\mathrm{A}}$ receptor antagonist bicuculline $(0.5$ $\mu \mathrm{g})$ into one lateral $\mathrm{SNr}(E)$ and saline injected into the opposite lateral $\mathrm{SNr}(F)$. $S T$, Dorsomedial striatum; ST lat, dorsolateral striatum; $L V$, lateral ventricle. Scale bar, $250 \mu \mathrm{m}$. dopamine neurons would increase dopamine release in striatum/ NAc and induce Fos. Injections of the $\mathrm{GABA}_{\mathrm{A}}$ receptor antagonist bicuculline into $\mathrm{SNr}$ /VTA produce dopamine release (Westerink et al., 1996), rotational behavior (Kozlowski and Marshall, 1980), and self-administration (David et al., 1997; Ikemoto et al., 1997) and induce Fos in ipsilateral striatum in this study.

Systemic morphine induces Fos in dorsomedial striatum and to a lesser extent in NAc (Liu et al., 1994; present study). This pattern of Fos induction was mimicked by morphine injections into medial $\mathrm{SNr}$ and VTA but was not reproduced by lateral $\mathrm{SNr}$ injections. This suggests that systemic morphine acts preferentially on medial SNr and on VTA to induce Fos in dorsomedial striatum and NAc. This might occur because of a higher density or some other property of $\mu$ receptors in medial SNr and VTA compared with lateral SNr (McLean et al., 1986; Mansour et al., 1987; Temple and Zukin, 1987; German et al., 1993).
Injections of the $\mu_{1}$ opioid receptor antagonist naloxonazine into SNr did not completely block the induction of Fos in striatum and NAc produced by systemic administration of morphine, raising the possibility that $\mu$ receptors in other locations or other opiate receptor subtypes that are located within or outside the SN modulate Fos induction (Loh and Smith, 1990; Miyamoto et al., 1993). The finding that naloxonazine injections into the VTA also reduced Fos induction in striatum is consistent with the proposal that systemic morphine acts on both medial SNr and VTA $\mu$ opioid receptors. Striatal $\mu$ opioid receptors might also play a role in inducing Fos in striatum after systemic morphine. If $\mu$ receptors were located on striatal GABAergic neurons that project to SNc dopamine neurons (Gerfen, 1992), then morphine would inhibit these cells, resulting in activation of SNc dopamine neurons and induction of Fos in striatum via the nigrostriatal pathway. 

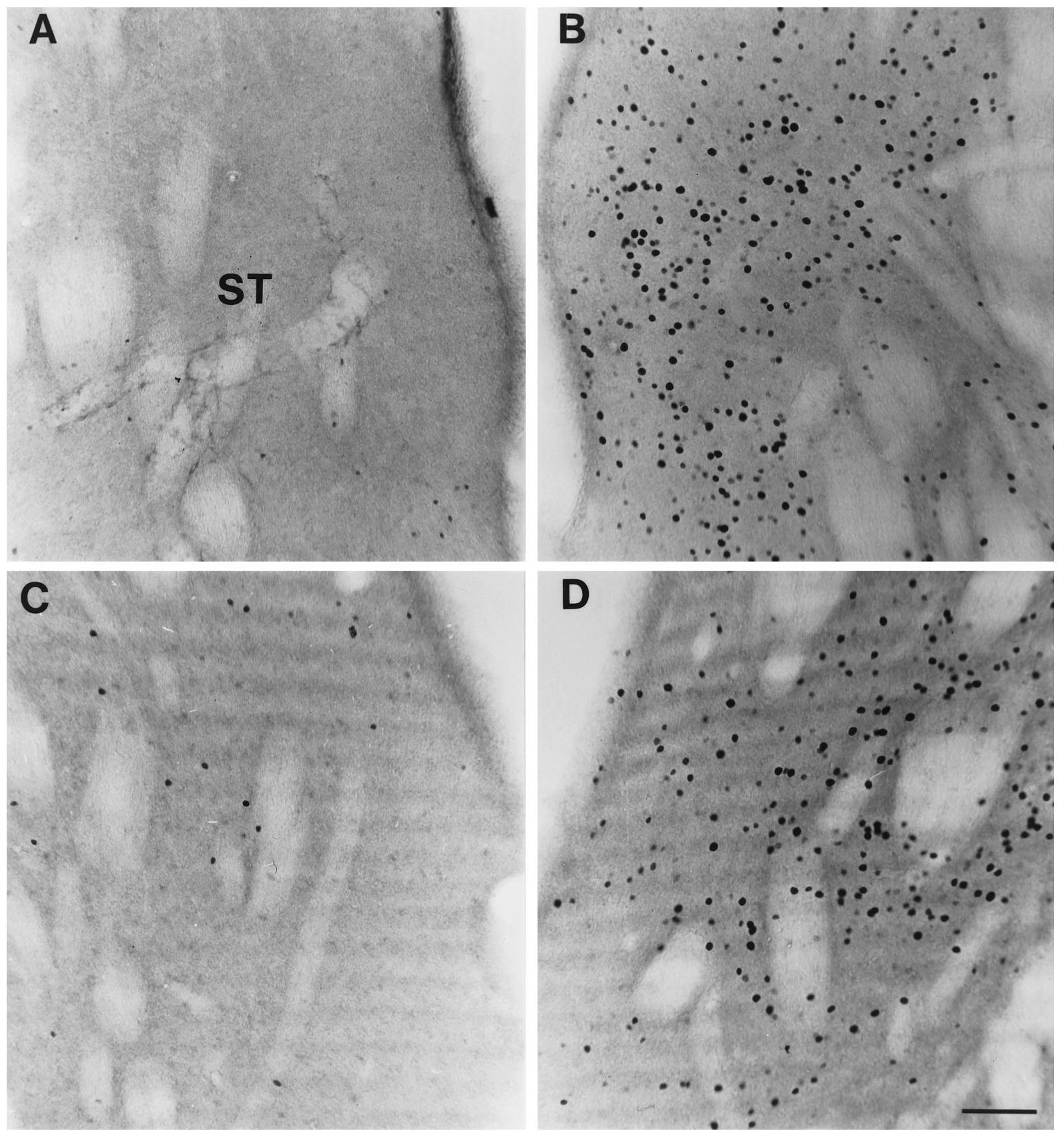

Figure 12. Fos protein induction in dorsomedial striatum after systemic administration of morphine $(10 \mathrm{mg} / \mathrm{kg}$, i.p., 4 times over $2 \mathrm{hr})$ in rats that had saline injected into one striatum $(B, D)$ and the NMDA glutamate receptor antagonist MK $801(0.1 \mu \mathrm{g})(A)$ or the $\mathrm{D}_{1}$ dopamine receptor antagonist SCH $23390(0.1 \mu \mathrm{g})(C)$ injected into the opposite striatum 30 min previously. Note that MK 801 and SCH 23390 markedly decreased Fos protein induction compared with the side injected with saline. $S T$, Striatum. Scale bar, $85 \mu \mathrm{m}$.

There are parallel circuits in the basal ganglia that process different classes of information (Alexander and Crutcher, 1990; Graybiel, 1990; Gerfen, 1992; Groenewegen and Berendse, 1994). The rat medial striatum and NAc receive afferent inputs from limbic-related structures (Groenewegen and Berendse, 1994), whereas the dorsolateral striatum receives predominant inputs from sensory and motor cortical areas (Brown and Sharp, 1995). Systemic morphine activates the limbic circuit, a property common to drugs of abuse (Di Chiara and Imperato, 1988b).

\section{Morphine injections into SN and VTA produce contralateral rotation}

Infusions of morphine, the $\mu$ receptor agonist DAMGO, and bicuculline into $\mathrm{SNr}$ or VTA produced contralateral turning behavior. This effect is consistent with infusions of morphine, enkephalin (Jenck et al., 1988), and DAMGO (Devine and Wise, 1994) into VTA or intranigral injections of morphine (Iwamoto and Way, 1977), other opiates (Morelli and Di Chiara, 1985), and GABA antagonists (Kozlowski and Marshall, 1980), which produce contralateral turning. Morphine increases dopamine release 

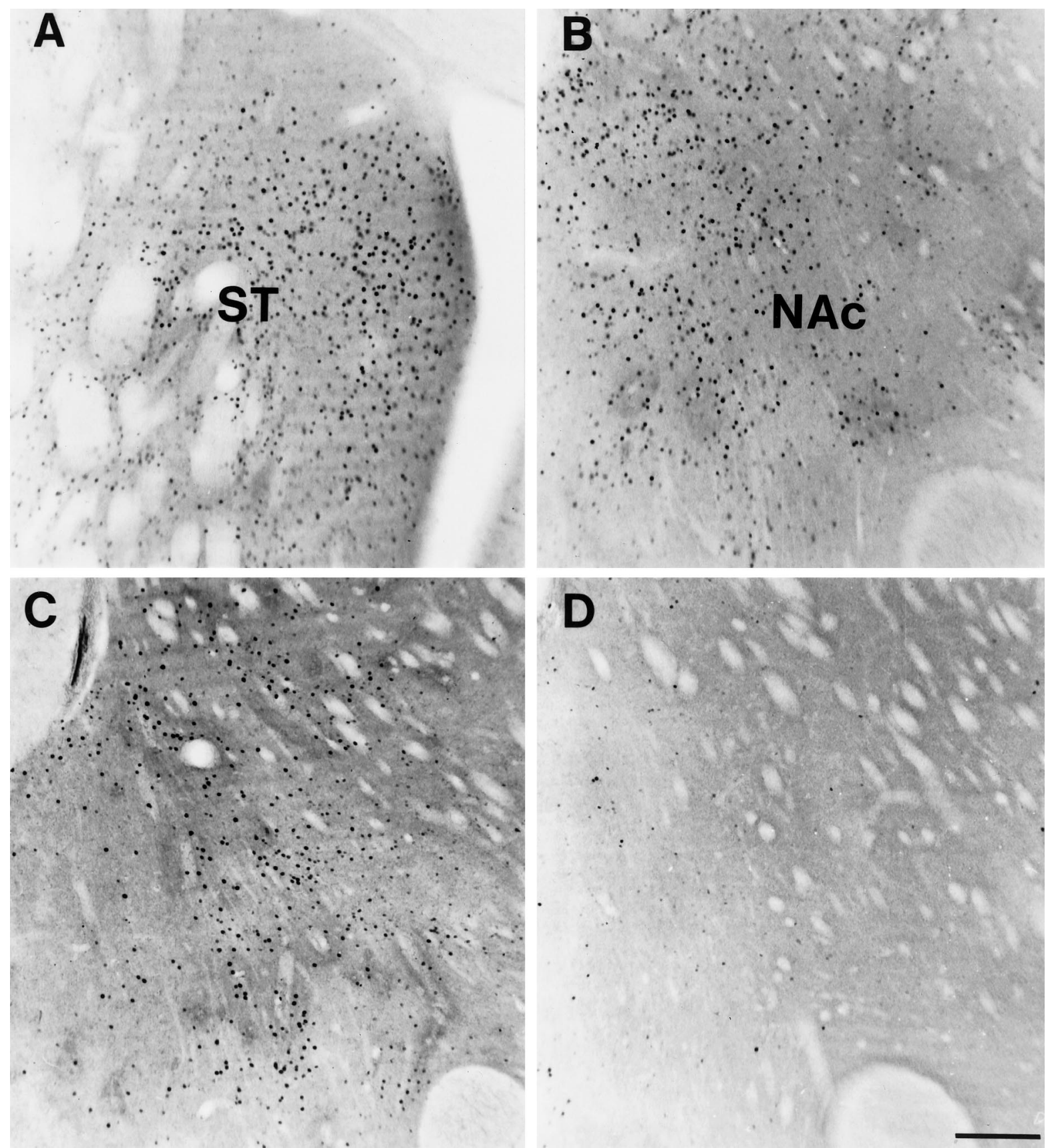

Figure 13. Photomicrographs of a rat dorsomedial striatum $(A)$ and nucleus accumbens $(N A C)(B)$ showing marked Fos protein induction 2 hr after morphine $(10 \mu \mathrm{g})$ injection into the ipsilateral VTA. Morphine injected into medial SNr also induced Fos protein in the NAc $(C)$ compared with little Fos induction after morphine injection into lateral SNr $(D)$. ST, Striatum. Scale bar, $200 \mu \mathrm{m}$.

in ipsilateral striatum to produce contralateral turning (Stinus et al., 1980; K. B. Johnson et al., 1992; Paul et al., 1992; Devine and Wise, 1994), although an alternative nondopaminergic mechanism has also been suggested (Morelli and Di Chiara, 1985).

Of interest is that the turning that was produced correlated with the number and pattern of striatal Fos-stained neurons. Although morphine injections into both SNr and VTA produced turning, the turning rate was greatest at high morphine doses and correlated best with morphine injections into middle and lateral $\mathrm{SNr}$, which induced Fos primarily in dorsolateral striatum. This is compatible with the topography of lateral $\mathrm{SNc}$ projections to lateral striatum and sensorimotor cortical projections to lateral striatum (Groenewegen and Berendse, 1994; Brown and Sharp, 1995; Graybiel, 1995; Hersch et al., 1995). In turning animals, Fos was also induced in the GP, a region that is involved in the control of movements (Alexander and Crutcher, 1990; Albin et al., 1995; Graybiel, 1995). $\mathrm{D}_{1}$ receptor activation can enhance or decrease evoked discharge in neostriatal medium spiny neurons, depending on the cellular depolarization and calcium flux through Ltype calcium channels (Hernández-López et al., 1997). Therefore, striatal $D_{1}$ neurons that contain substance $\mathrm{P}$, project to $\mathrm{SN}$, and send axon collaterals to the internal segments of the GP (Kawaguchi et al., 1990; Surmeier et al., 1996) could mediate induction of Fos in GP. This Fos induction indicates activation of 
the motor/sensory circuit, which might mediate the dopaminedependent motor syndromes reported after stimulation of intranigral opioid receptors (Morelli et al., 1989). Drugs that modulate opioid receptors might provide additional targets for the pharmacological treatment of motor disorders of the basal ganglia (Albin et al., 1995).

\section{Coactivation of $D_{1}$ and NMDA receptors mediates induction of Fos in striatum}

Systemic administration of either $\mathrm{D}_{1}$ or NMDA receptor antagonists blocks Fos induction in striatum produced by systemic administration of cocaine, amphetamine (Graybiel et al., 1990; Snyder-Keller, 1991; Young et al., 1991; Torres and Rivier, 1993), and morphine (Liu et al., 1994). In the present study, local striatal injections of either $D_{1}$ or NMDA receptor antagonists were sufficient to completely block Fos induction in striatum produced by systemic morphine. These results suggest that coactivation of $\mathrm{D}_{1}$ dopamine and NMDA glutamate receptors located in striatum is necessary for Fos induction. The Fos induction produced by infusions of $N$-methyl-D-aspartate itself into striatum (Aronin et al., 1991) might also require $D_{1}$ receptor coactivation.

Blockade of Fos induction by striatal injections of $D_{1}$ and NMDA receptor antagonists means that Fos induction after systemic morphine must be mediated by both dopamine and glutamate inputs to striatum/NAc. The only sources of dopamine input to striatum and NAc are from the SNc/VTA dopamine neurons, suggesting that increased release of dopamine from $\mathrm{SNc}$ and VTA neurons is necessary for systemic morphine to induce Fos in striatum/NAc. The source of glutamate input to the striatum and NAc could be from cortex. Systemic morphine induces Fos in medial prefrontal, cingulate, and parietal cortices (Garcia et al., 1995). In fact, mesocortical and mesolimbic dopamine inputs to limbic cortex could modulate Fos induction in cortical neurons. Alternatively, cortical neurons may be activated by alterations in thalamocortical projections (Berendse and Groenewegen, 1991). Cortical pyramidal neurons projecting to striatum and NAc (Berendse et al., 1992) would release glutamate and activate NMDA receptors, which along with coincident release of dopamine and activation of $\mathrm{D}_{1}$ receptors could induce Fos in striatal/NAc neurons.

There are several possible mechanisms that could explain this $\mathrm{D}_{1} / \mathrm{NMDA}$ receptor coactivation. NMDA receptors may be located presynaptically on dopamine terminals and modulate dopamine release in striatum (Leviel et al., 1990; Krebs et al., 1991; Wang, 1991; Martinez-Fong et al., 1992). MK 801 could block presynaptic NMDA receptors on striatal/NAc dopamine terminals, block dopamine release normally produced by morphine, and prevent Fos induction.

NMDA receptors mediating Fos induction could also be located postsynaptically. Because $\mathrm{D}_{1}$ receptors in striatum/NAc are believed to be postsynaptic, it is possible that the $D_{1}$ and NMDA receptors are located on the same cell in which Fos is induced. This would suggest that concurrent activation of NMDA and $\mathrm{D}_{1}$ receptors would be required for Fos induction. The Fos promoter is known to have the adenylate cyclase response (CRE) and serum response (SRE) elements, responsive to cAMP and calcium, respectively (Bading et al., 1993). Dopamine binding to $\mathrm{D}_{1}$ receptors would activate $\mathrm{CAMP}, \mathrm{CREB}$, and binding to the CRE. Glutamate binding to NMDA receptors would induce calcium entry and activate the SRE. Although there is the suggestion that either element can induce Fos in vitro (Bading et al., 1993), recent in vivo transgenic mutation of any one of the $c$-fos promoter elements was sufficient to block Fos induction (Robertson et al., 1995). In addition, if there is not sufficient calcium in the cell, c-fos transcription is blocked (Collart et al., 1991). Last, blockade of NMDA receptors in cultured cortical neurons prevents Fos activation by many different stimuli, including potassium and phorbol esters (Hisanaga et al., 1992), and blockade of NMDA receptors in striatal neurons prevents Fos induction by dopamine and phorbol esters (Konradi et al., 1996). These data suggest that coactivation of $\mathrm{D}_{1}$ and NMDA receptors and coactivation of $\mathrm{CRE}$ and SRE in the $c$-fos promoter are required for Fos induction in single striatal cells.

$\mathrm{D}_{1}$ and NMDA receptor antagonists prevent $c$-fos and junB induction in striatum and NAc produced by morphine (Liu et al., 1994; present study), amphetamine, and cocaine (Graybiel et al., 1990; Young et al., 1991; Berretta et al., 1992; Moratalla et al., 1993), and they block the reward and other properties of drugs of abuse (Trujillo and Akil, 1991; Koob, 1992; Maldonado et al., 1993; Shippenberg et al., 1993). These findings suggest that the $\mathrm{D}_{1} / \mathrm{NMDA}$ receptor regulation of IEG induction in striatum and NAc could modulate the expression of target genes that may be involved in the establishment of long-term changes in neural circuits underlying some of the behavioral effects of addictive drugs. Further investigations will have to elucidate the nature and the functional role of these target genes (Nye and Nestler, 1996; Sganga et al., 1996).

\section{REFERENCES}

Akil H, Watson SJ, Young E, Lewis ME, Khachaturian H, Walker JM (1984) Endogenous opioids: biology and function. Annu Rev Neurosci 7:223-255.

Albin RL, Young AB, Penney JB (1995) The functional anatomy of disorders of the basal ganglia. Trends Neurosci 18:63-64.

Alexander GE, Crutcher MD (1990) Functional architecture of basal ganglia circuits: neural substrates of parallel processing. Trends Neurosci 13:266-271.

Aronin N, Chase K, Sagar SM, Sharp FR, DiFiglia M (1991) N-methylD-aspartate receptor activation in the neostriatum increases c-fos and fos-related antigens selectively in medium-sized neurons. Neuroscience 44:409-420.

Bading H, Ginty DD, Greenberg ME (1993) Regulation of gene expression in hippocampal neurons by distinct calcium signalling pathways. Science 260:181-186.

Berendse HK, Groenewegen HJ (1991) Restricted cortical termination fields of the midline and intralaminar thalamic nuclei in the rat. Neuroscience 42:73-102.

Berendse HK, Galis-de-Graaf Y, Groenewegen HJ (1992) Topographical organization and relationship with ventral striatal compartments of prefrontal corticostriatal projections in the rat. J Comp Neurol 316:314-347.

Berretta S, Robertson HA, Graybiel AM (1992) Dopamine and glutamate agonists stimulate neuron-specific expression of Fos-like protein in the striatum. J Neurophysiol 68:767-777.

Bhargava HN, Villar VM, Rahmani NH, Larsen KA (1992) Time course of the distribution of morphine in brain regions and spinal cord after intravenous injection to spontaneously hypertensive and normotensive Wistar-Kyoto rats. J Pharmacol Exp Ther 261:1008-1014.

Boja JW, Vaughan R, Patel A, Shaya EK, Kuhar MJ (1994) The dopamine transporter. In: Dopamine receptors and transporter: pharmacology, structure and function (Niznik HB, ed), pp 611-644. New York: Dekker M.

Bontempi B, Liu J, Massa SS, Sharp FR (1995) Intracerebral injection of morphine into the substantia nigra induces c-fos protein in striatum associated with rotational behavior. Soc Neurosci Abstr 21:1849.

Bozarth MA, Wise RA (1984) Anatomically distinct opiate receptor fields mediate reward and physical dependence. Science 224:516-517.

Brown LL, Sharp FR (1995) Metabolic mapping of rat striatum: somatotopic organization of sensorimotor activity. Brain Res 686:207-222.

Cenci MA, Campbell K, Wictorin K, Bjorklund A (1992) Striatal c-fos induction by cocaine or apomorphine occurs preferentially in output 
neurons projecting to the substantia nigra in the rat. Eur $\mathbf{J}$ Neurosci 4:376-380.

Chang SL, Squinto SP, Harlan RE (1988) Morphine activation of c-fos expression in rat brain. Biochem Biophys Res Commun 157:698-704.

Cole AJ, Bhat RV, Patt C, Worley PF, Baraban JM (1992) D 1 dopamine receptor activation of multiple transcription factor genes in the rat striatum. J Neurochem 58:1420-1426.

Collart MA, Tourkine N, Belin D, Vassalli P, Jeanteur P, Blanchard J-M (1991) c-fos gene transcription in murine macrophages is modulated by a calcium-dependent block to elongation in intron 1. Mol Cell Biol 11:2826-2831.

Cooper JR, Bloom FE, Roth RH (1991) The biochemical basis of neuropharmacology, 6th edition. New York: Oxford UP.

Cruciani RA, Lutz RA, Munson PJ, Rodbard D (1987) Naloxonazine effects on the interaction of enkephalin analogs with $\mathrm{Mu}-1, \mathrm{Mu}$ and Delta opioid binding sites in rat brain membranes. J Pharmacol Exp Ther 242:15-20.

David V, Cazala P (1994) Differentiation of intracranial morphine selfadministration behavior among five brain regions in mice. Pharmacol Biochem Behav 48:625-633.

David V, Durkin TP, Cazala P (1997) Self-administration of the $\mathrm{GABA}_{\mathrm{A}}$ antagonist bicuculline into the ventral tegmental area in mice: dependence on $\mathrm{D}_{2}$ dopaminergic mechanisms. Psychopharmacology 130:85-90.

De Togni P, Niman H, Raymond V, Sawchenko P, Verma IM (1988) Detection of Fos protein during osteogenesis by monoclonal antibodies. Mol Cell Biol 8:2251-2256.

Devine DP, Wise RA (1994) Self-administration of morphine, DAMGO, and DPDPE into the ventral tegmental area of rats. J Neurosci 14:1978-1984.

Devine DP, Leone P, Pocock D, Wise RA (1993) Differential involvement of ventral tegmental $\mathrm{Mu}$, Delta, and Kappa opioid receptors in modulation of basolimbic dopamine release: in vitro microdialysis studies. J Pharmacol Exp Ther 266:1236-1246.

Di Chiara G, Imperato A (1988a) Drugs abused by humans preferentially increase synaptic dopamine concentrations in the mesolimbic system of freely moving rats. Proc Natl Acad Sci USA 85:5274-5278.

Di Chiara G, Imperato A (1988b) Opposite effects of $\mathrm{Mu}$ and Kappa opiate agonists on dopamine release in the nucleus accumbens and in the dorsal caudate of freely moving rats. J Pharmacol Exp Ther 244:1067-1080.

Di Chiara G, North RA (1992) Neurobiology of opiate abuse. Trends Pharmacol Sci 13:185-193.

Fallon JH, Moore RY (1978) Catecholamine innervation of the basal forebrain: IV. Topography of the dopamine projection to the basal forebrain and neostriatum. J Comp Neurol 180:545-580.

Fitzgerald LW, Ortiz J, Hamedani AG, Nestler EJ (1996) Drugs of abuse and stress increase the expression of GluR1 and NMDAR1 glutamate receptor subunits in the rat ventral tegmental area: common adaptations among cross-sensitizing agents. J Neurosci 16:274-282.

Fowler CJ, Fraser GL (1994) $\mu-, \delta-, \kappa$-opioid receptors and their subtypes. A critical review with emphasis on radioligand binding experiments. Neurochem Int 24:401-426.

Garcia MM, Brown HE, Harlan RE (1995) Alterations in immediateearly gene proteins in the rat forebrain induced by acute morphine injection. Brain Res 692:23-40.

Gerfen CR (1992) The neostriatal mosaic: multiple levels of compartmental organization. Trends Neurosci 15:133-139.

Gerfen CR, Engber TM, Mahan LC, Susel Z, Chase TN, Monsma Jr FJ, Sibley DR (1990) $\mathrm{D}_{1}$ and $\mathrm{D}_{2}$ dopamine receptor-regulated gene expression of striatonigral and striatopallidal neurons. Science 250:1429-1432.

German DC, Speciale SG, Manaye KF, Sadeq M (1993) Opioid receptors in midbrain dopaminergic regions of the rat. I. $\mathrm{Mu}$ receptor autoradiography. J Neural Transm 91:39-52.

Graybiel AM (1990) Neurotransmitters and neuromodulators in the basal ganglia. Trends Neurosci 13:244-254.

Graybiel AM (1995) The basal ganglia. Trends Neurosci 18:60-62.

Graybiel AM, Moratalla R, Robertson HA (1990) Amphetamine and cocaine induce drug-specific activation of the c-fos gene in striosomematrix and limbic subdivisions of the striatum. Proc Natl Acad Sci USA 87:6912-6916.

Groenewegen HJ, Berendse HW (1994) The specificity of the "nonspecific" midline and intralaminar thalamic nuclei. Trends Neurosci 17:52-57.
Hernández-López S, Bargas J, Surmeier DJ, Reyes A, Galarraga E (1997) $\mathrm{D}_{1}$ receptor activation enhances evoked discharge in neostriatal medium spiny neurons by modulating an L-type $\mathrm{Ca}^{2+}$ conductance. J Neurosci 17:3334-3342.

Hersch SM, Ciliax BJ, Gutekunst C-Y, Rees HD, Heilman CJ, Uung KKL, Bolam JP, Ince E, Yi H, Levey AI (1995) Electron microscopic analysis of $\mathrm{D}_{1}$ and $\mathrm{D}_{2}$ dopamine receptor proteins in the dorsal striatum and their synaptic relationships with motor corticostriatal afferents. J Neurosci 15:5222-5237.

Hisanaga K, Sagar SM, Hicks KJ, Sharp FR (1992) NMDA antagonists block Fos-like nuclear protein expression induced by multiple signalling pathways in cultured cortical neurons. J Neurochem 58:1836-1844.

Hoffman BJ (1994) Molecular biology of dopamine transporters. In: Dopamine receptors and transporter: pharmacology, structure and function (Niznik HB, ed), pp 645-668. New York: Dekker M.

Hope B, Kosofsky B, Hyman SE, Nestler EJ (1992) Regulation of immediate early gene expression and AP-1 binding in the rat nucleus accumbens by chronic cocaine. Proc Natl Acad Sci USA 89:5764-5768.

Ikemoto S, Murphy JM, McBride WJ (1997) Self-infusion of GABA antagonists directly into the ventral tegmental area and adjacent regions. Behav Neurosci 111:369-380.

Iwamoto ET, Way EL (1977) Circling behavior and stereotypy induced by intranigral opiate microinjections. J Pharmacol Exp Ther 203:347-359.

Jenck F, Bozarth MA, Wise RA (1988) Contraversive circling induced by ventral tegmental microinjections of moderate doses of morphine and [D-Pen ${ }^{2}$, D-Pen ${ }^{5}$ ]enkephalin. Brain Res 450:382-386.

Johansson B, Lindstrom K, Fredholm BB (1994) Differences in the regional and cellular localization of c-fos mRNA induced by amphetamine, cocaine and caffeine. Neuroscience 59:837-849.

Johnson KB, Criswell HE, Jensen KF, Simson PE, Mueller RA, Breese GR (1992) Comparison of the D-1 dopamine agonists SKF-38393 and A-68930 in neonatal 6-hydroxydopamine-lesioned rats: behavioral effects and induction of c-fos-like immunoreactivity. J Pharmacol Exp Ther 262:855-865.

Johnson SW, North RA (1992) Opioids excite dopamine neurons by hyperpolarization of local interneurons. J Neurosci 12:483-488.

Johnson SW, Seutin V, North RA (1992) Burst firing in dopamine neurons induced by $N$-methyl-D-aspartate: role of electrogenic pump. Science 258:665-667.

Kawaguchi Y, Wilson CJ, Emson PC (1990) Projection subtypes of rat neostriatal matrix cells revealed by intracellular injection of biocytin. J Neurosci 10:3421-3438.

Konradi C, Leveque J-C, Hyman SE (1996) Amphetamine and dopamine-induced immediate early gene expression in striatal neurons depends on postsynaptic NMDA receptors and calcium. J Neurosci 16:4231-4239.

Koob GF (1992) Drugs of abuse: anatomy, pharmacology and function of reward pathways. Trends Pharmacol Sci 13:177-184.

Koob GF, Bloom FE (1988) Cellular and molecular mechanisms of drug dependence. Science 242:715-723.

Kosofsky BE, Genova LM, Hyman SE (1995) Substance P phenotype defines specificity of c-fos induction by cocaine in developing rat striatum. J Comp Neurol 351:41-50.

Kozlowski MR, Marshall JF (1980) Rotation induced by intranigral injections of GABA agonists and antagonists: zone specific effects. Pharmacol Biochem Behav 13:561-567.

Krebs MO, Trovero F, Desban M, Gauchy C, Glowinski J, Kemel ML (1991) Distinct presynaptic regulation of dopamine release through NMDA receptors in striosome- and matrix-enriched areas of the rat. J Neurosci 11:1256-1262.

Laugwitz K-L, Offermanns S, Spicher K, Schultz G (1992) $\mu$ and $\delta$ opioid receptors differentially couple to $\mathrm{G}$ protein subtypes in membranes of human neuroblastoma SH-SY5Y cells. Neuron 10:233-242.

Leviel V, Gobert A, Guibert B (1990) The glutamate-mediated release of dopamine in the rat striatum: further characterization of the dual excitatory-inhibitory function. Neuroscience 39:305-312.

Liu J, Nickolenko J, Sharp FR (1994) Morphine induces c-fos and junB in striatum and nucleus accumbens via $\mathrm{D}_{1}$ and $N$-methyl-D-aspartate receptors. Proc Natl Acad Sci USA 91:8537-8541.

Loh HH, Smith AP (1990) Molecular characterization of opioid receptors. Annu Rev Pharmacol Toxicol 30:123-147.

Maldonado R, Robledo P, Chover AJ, Caine SB, Koob GF (1993) D dopamine receptors in the nucleus accumbens modulate cocaine selfadministration in the rat. Pharmacol Biochem Behav 45:239-242. 
Mansour A, Khachaturian H, Lewis ME, Akil H, Watson SJ (1987) Autoradiographic differentiation of $\mathrm{Mu}$, Delta, and Kappa opioid receptors in the rat forebrain and midbrain. J Neurosci 7:2445-2464.

Martinez-Fong D, Rosales MG, Gongora-Alfaro JL, Hernandez S, Acebes J (1992) NMDA receptor mediates dopamine release in the striatum of unanesthetized rats as measured by brain microdialysis. Brain Res 595:309-315.

Matthews RT, German DC (1984) Electrophysiological evidence for excitation of rat ventral tegmental area dopamine neurons by morphine. Neuroscience 11:617-625.

McLean S, Rothman RD, Herkenham M (1986) Autoradiographic localization of $\mathrm{Mu}$ and Delta receptors in the forebrain of the rat. Brain Res 378:49-60.

Miyamoto Y, Portoghese PS, Takemori AE (1993) Involvement of Delta-2 opioid receptors in acute dependence on morphine in mice. J Pharmacol Exp Ther 265:1325-1327.

Moratalla R, Vickers EA, Robertson HA, Cochran BH, Graybiel AM (1993) Coordinate expression of c-fos and jun B is induced in the rat striatum by cocaine. J Neurosci 13:423-433.

Moratalla R, Elibol B, Vallejo M, Graybiel AM (1996) Network-level changes in expression of inductible Fos-Jun proteins in the striatum during chronic cocaine treatment and withdrawal. Neuron 17:147-156.

Morelli M, Di Chiara G (1985) Non-dopaminergic mechanisms in the turning behavior evoked by intranigral opiates. Brain Res 341:350-359.

Morelli M, Fenu S, Di Chiara G (1989) Substantia nigra as a site of origin of dopamine-dependent motor syndromes induced by stimulation of $\mu$ and $\delta$ opioid receptors. Brain Res 487:120-130.

Nestler EJ (1992) Molecular mechanisms of drug addiction. J Neurosci 12:2439-2450.

Nestler EJ, Hope BT, Widnell KL (1993) Drug addiction: a model for the molecular basis of neural plasticity. Neuron 11:995-1006.

Nock B, Giordano AL, Moore BW, Cicero TJ (1993) Properties of the putative epsilon opioid receptor: identification in rat, guinea pig, cow, pig and chicken brain. J Pharmacol Exp Ther 264:349-359.

Nye HE, Nestler EJ (1996) Induction of chronic Fos-related antigens in rat brain by chronic morphine administration. Mol Pharmacol 49:636-645.

Paul ML, Graybiel AM, David J-C, Robertson HA (1992) $D_{1}$-like and $\mathrm{D}_{2}$-like dopamine receptors synergistically activate rotation and c-fos expression in the dopamine-depleted striatum in a rat model of Parkinson's disease. J Neurosci 12:3729-3742.

Paxinos G, Watson C (1986) The rat brain in stereotaxic coordinates, second edition. Sydney: Academic.

Robertson HA, Paul ML, Moratalla R, Graybiel AM (1991) Expression of the immediate early gene c-fos in basal ganglia: induction by dopaminergic drugs. Can J Neurol Sci 18:380-383.

Robertson LM, Kerppola TK, Vendrell M, Luk D, Smeyne RJ, Bocchiaro C, Morgan JI, Curran T (1995) Regulation of c-fos expression in transgenic mice requires multiple interdependent transcription control elements. Neuron 14:241-252.

Robertson S, Vincent SR, Fibiger HC (1990) Striatonigral projection neurons contain $\mathrm{D}_{1}$ dopamine receptor activated c-fos. Brain Res 523:288-290.

Sganga MW, Bontempi B, Baner K, Massa S, Sagar S, Sharp FR (1996)
Comparison of neuronal gene induction by different drugs of addiction using immunocytochemistry and two-dimensional protein electrophoresis. Soc Neurosci Abstr 22:407.

Sharp, FR, Sagar SM (1995) Localization of c-fos gene expression in brain using in situ hybridization autoradiography and immunocytochemistry. In: Autoradiography and correlative imaging (Stumpf WE, Solomon HF, eds), pp 441-463. San Diego: Academic.

Sharp FR, Sagar SM, Hicks K, Lowenstein D, Hisanaga K (1991) c-fos mRNA, Fos, and Fos-related antigen induction by hypertonic saline and stress. J Neurosci 11:2321-2331.

Shippenberg TS, Bals-Kubik R, Herz A (1993) Examination of the neurochemical substrates mediating motivational effects of opioids: role of the mesolimbic dopamine system and $D_{1}$ vs. $D_{2}$ dopamine receptors. J Pharmacol Exp Ther 265:53-59.

Snyder-Keller AM (1991) Striatal c-fos induction by drugs and stress in neonatally dopamine-depleted rats given nigral transplants: importance of NMDA activation and relevance to sensitization phenomena. Exp Neurol 113:155-165.

Spangel R, Herz A, Shippenberg TS (1990) The effects of opioid peptides on dopamine release in the nucleus accumbens: an in vivo microdialysis study. J Neurochem 55:1734-1740.

Steiner H, Gerfen CR (1993) Cocaine-induced c-fos messenger RNA is inversely related to dynorphin expression in striatum. J Neurosci 13:5066-5081.

Steiner H, Gerfen CR (1995) Dynorphin opioid inhibition of cocaineinduced, $\mathrm{D}_{1}$ dopamine receptor-mediated immediate early gene expression in striatum. J Comp Neurol 353:200-212.

Stinus L, Koob GF, Ling N, Bloom FE, LeMoal M (1980) Locomotor activation induced by inf usion of endorphins into the ventral tegmental area: evidence for opiate-dopamine interactions. Proc Natl Acad Sci USA 77:2323-2329.

Surmeier DJ, Song W-J, Yan Z (1996) Coordinated expression of dopamine receptors in neostriatal medium spiny neurons. J Neurosci 16:6579-6591.

Temple A, Zukin RS (1987) Neuroanatomical patterns of the $\mu, \delta$, and $\kappa$ opioid receptors of rat brain as determined by quantitative in vitro autoradiography. Proc Natl Acad Sci USA 84:4308-4312.

Torres G, Rivier C (1993) Cocaine-induced expression of striatal c-fos in the rat is inhibited by NMDA receptor antagonists. Brain Res Bull 30:173-176.

Trujillo KA, Akil H (1991) Inhibition of morphine tolerance and dependence by the NMDA receptor antagonist MK-801. Science 251:85-87.

Wang JK (1991) Presynaptic glutamate receptors modulate dopamine release from striatal synaptosomes. J Neurochem 57:819-822.

Westerink BHC, Kwint H-F, deVries JB (1996) The pharmacology of mesolimbic dopamine neurons: a dual-probe microdialysis study in the ventral tegmental area and nucleus accumbens of the rat brain. J Neurosci 16:2605-2611.

Wise RA, Rompre P-P (1989) Brain dopamine and reward. Annu Rev Psychol 40:191-255.

Young ST, Porrino LJ, Iadarola MJ (1991) Cocaine induces striatal c-Fos-immunoreactive proteins via dopaminergic $D_{1}$ receptors. Proc Natl Acad Sci USA 88:1291-1295. 